\title{
Modeling potential impacts of three benthic invasive species on the Lake Erie food web
}

\author{
Hongyan Zhang (iD · Edward S. Rutherford - Doran M. Mason - Marion E. Wittmann • \\ David M. Lodge $\cdot$ Xinhua Zhu $\cdot$ Timothy B. Johnson $\cdot$ Andrew Tucker
}

Received: 21 April 2018/Accepted: 29 January 2019/Published online: 14 February 2019

(C) The Author(s) 2019

\begin{abstract}
Assessing the potential for aquatic invasive species (AIS) to impact ecosystem function and services is an important component of ecological risk assessment. This study focuses on quantifying changes in biomass of food web groups in response to changes in AIS biomass as a function of variable AIS prey vulnerabilities (i.e. food availability) and AIS vulnerabilities to predators (i.e. predation pressure). We modified an existing Lake Erie food web model to assess the potential food web impacts of three benthic AIS (Eurasian ruffe Gymnocephalus cernua, killer
\end{abstract}

Electronic supplementary material The online version of this article (https://doi.org/10.1007/s10530-019-01929-7) contains supplementary material, which is available to authorized users.

H. Zhang ( $\square)$

Cooperative Institute for Great Lakes Research,

University of Michigan, Ann Arbor, MI 48108, USA

e-mail: hongyanzhang2012@gmail.com

E. S. Rutherford · D. M. Mason

NOAA Great Lakes Environmental Research Laboratory, Ann Arbor, MI 48108, USA

M. E. Wittmann

University of California, Santa Barbara, Natural Reserve

System, Santa Barbara, CA, USA

D. M. Lodge

Department of Ecology and Evolutionary Biology,

Atkinson Center for a Sustainable Future, Cornell

University, Ithaca, NY, USA shrimp Dikerogammarus villosus, and golden mussel Limnoperna fortunei) that may invade Lake Erie in the near future. Simulated biomass of golden mussels was most affected by bottom-up control, while killer shrimp and ruffe were affected by both top-down and bottom-up controls. AIS food web impacts showed both monotonic and non-monotonic responses to AIS biomass. Impacts from ruffe were highest when their biomass was high, while killer shrimp and golden mussels had maximal impacts at intermediate biomass levels on some food web groups. Our results suggest that golden mussels, which can feed at a lower trophic level and have fewer predators than ruffe or killer shrimp, may reach much higher equilibrium biomass under some scenarios and affect a broader range of food web groups. While all three species may induce

X. Zhu

Fisheries and Oceans Canada, Winnipeg, MB R3T 2N6, Canada

\section{T. B. Johnson}

Ontario Ministry of Natural Resources and Forestry, Picton, ON K0K 2T0, Canada

A. Tucker

The Nature Conservancy, South Bend, IN, USA 
negative effects if introduced to Lake Erie, golden mussels may pose the highest risk of impact for Lake Erie's food web.

Keywords Risk assessment - Biological invasion · Ecological impacts · Great Lakes · Ecopath with Ecosim

\section{Introduction}

Biological invasions, especially unintentional introductions, have increased in recent decades in spatial scale, frequency and number of species involved as a consequence of the expansion of worldwide commerce, fluvial transport of goods, and range expansion (Darrigran and Damborenea 2011; Drake and Lodge 2004; Levine and D'Antonio 2003; Seebens et al. 2013), which may be further enhanced by climate and land use changes (Mandrak 1989; Vilà and Pujadas 2001). These invasive species are often tolerant of a wide range of environmental conditions, have rapid growth rates and high reproductive rates, and low vulnerability to natural predators (Boltovskoy et al. 2006a; Ogle 1998; Simberloff 2013), which allows them to rapidly exploit food and habitat resources, out compete native species, or modify habitat. As a result of these introductions and characteristics, ecosystem services are often diminished (Davidson et al. 1999; Dorcas et al. 2012; Vanderploeg et al. 2002).

Cost estimates for invasive species damage and control amount to approximately $\$ 134$ billion/year worldwide (Marbuah et al. 2014; Pimentel et al. 2005), and management challenges increase significantly once an invasive species becomes established (Leung et al. 2002; Lodge et al. 2016). Given the profound changes in ecosystem structures and functions that an invasive species can cause (Dorcas et al. 2012; Vanderploeg et al. 2002, 2015), a priori information about impacts is increasingly warranted for a robust and well-rounded ecological risk assessment of nonindigenous species that have potential to be invasive, in order to prioritize prevention or control efforts and optimize management resources.

Predicting the potential impacts of an invasive species is challenging. Most studies either make predictions using information on the invasion history of the invasive species and its impacts on invaded environments (Howeth et al. 2016; Keller and Drake 2009; Kulhanek et al. 2011), or focus on the direct impacts of the invasive species on their prey or competitors (Church et al. 2017; Dick et al. 2014; Laverty et al. 2017). These studies often ignore species interactions and indirect food web effects of the receiving environment, which may affect the population biomass that an invasive species can obtain and which is an important predictor of its ecological impacts (Goudswaard et al. 2008; Harrington et al. 2009; Lodge 1993; Parker et al. 1999). Food web models can simulate the population changes of the invasive species within the receiving environment, and capture the direct and indirect trophic effects of invasive species on the whole food web (BlukaczRichards and Koops 2012; Kao et al. 2014; Kitchell et al. 2000), providing a comprehensive prediction of invasive species establishment and impacts (David et al. 2017).

In this study, we modified the food web model developed by Zhang et al. (2016) to predict impacts of three potential benthic invaders that concern management agencies in the Laurentian Great Lakes. The species are: a fish (Eurasian ruffe Gymnocephalus сегииa), an amphipod (killer shrimp Dikerogammarus villosus) and a bivalve (golden mussel Limnoperna fortunei). All three are present on numerous regional watch lists and regulated species lists (Great Lakes Aquatic Nonindigenous Species Information System, GLANSIS https://www.glerl.noaa.gov/glansis/). For example, Eurasian ruffe (hereafter, 'ruffe') is prohibited in all Great Lakes jurisdictions, while golden mussel and killer shrimp each is regulated by five out of eight Great Lakes US states and both Canadian provinces that border the Great Lakes. Of these three species, only ruffe is known to occur already in the Great Lakes (and only in lakes Superior and Michigan). These species represent different functional groups feeding at different trophic levels, have different feeding methods, and different levels of predation risk. Understanding these differences between functional groups may provide general qualitative insights as to what to expect if the functional groups were to invade a particular ecosystem. In this regard, we hypothesize that (1) species that feed at a lower trophic level and access a greater prey biomass will reach a higher equilibrium biomass; (2) for species feeding at the same trophic level, equilibrium biomass will be modified by vulnerability to predators; and (3) 
species that have higher equilibrium biomass will have a greater impact on the food web.

\section{Methods}

Study area

Of all the Laurentian Great Lakes, Lake Erie (Fig. 1) is the smallest (area $=25,670 \mathrm{~km}^{2}$ ), the most biologically productive, and has the most nonindigenous aquatic species (https://www.glerl.noaa.gov/glansis/). We selected Lake Erie for this exercise because a food web model already exists (Zhang et al. 2016) and the lake is potentially accessible to ruffe, killer shrimp, and golden mussel. Lake Erie receives its major inflow and nutrient loads from the Detroit River, Maumee River and Sandusky River on the west, and discharges its major outflow through the Niagara River into Lake Ontario on the east (Maccoux et al. 2016). Lake Erie has three distinct basins: the western basin is shallow (mean depth $=8 \mathrm{~m}$ ) and eutrophic, the central basin is mesotrophic with seasonal thermal stratification during summer $($ mean depth $=18 \mathrm{~m}$ ), while the eastern basin is oligotrophic and deep with a more extensive hypolimnion (mean depth $=25 \mathrm{~m}$ ) (Bolsenga and Herdendorf 1993). The distinct basins provide a variety of habitats in terms of depth, water temperature and biological productivity. Moreover, Lake Erie provides a valuable recreational fishery and the largest commercial fishery among the Great Lakes in terms of total catch and economic value (Baldwin et al. 2009; USGS 2015). Walleye Sander vitreus, yellow perch Perca flavescens and rainbow smelt Osmerus mordax are the major commercially harvested species, while walleye, yellow perch, rainbow trout Oncorhynchus mykiss, and smallmouth bass Micropterus dolomieu are among the most popular recreational species (ODW 2017).

\section{Study species}

Ruffe are native to the Ponto-Caspian region and North Sea basin. This species was accidentally introduced into parts of France, the United Kingdom, Germany, Italy, and the upper Great Lakes (Pratt et al.

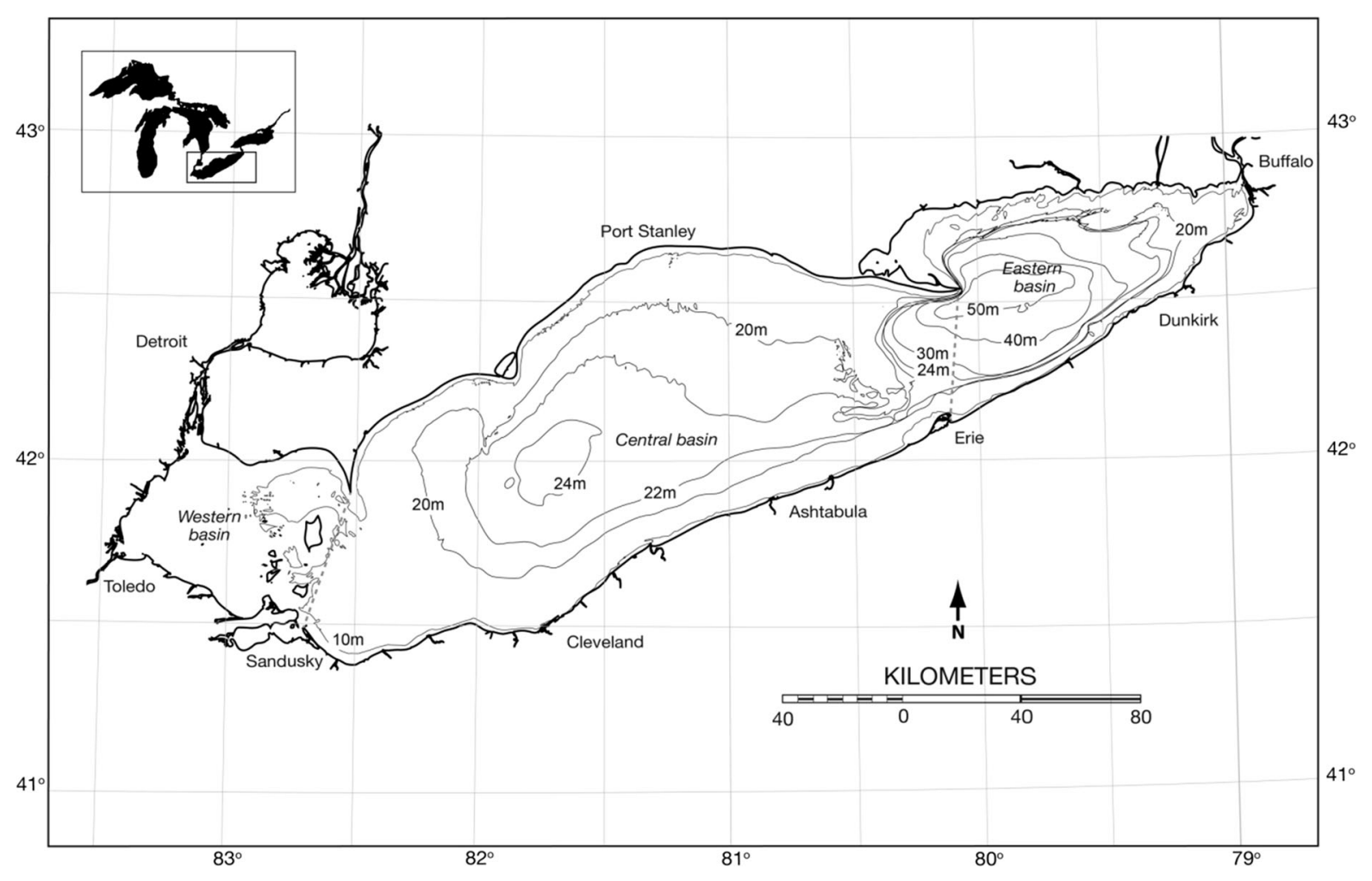

Fig. 1 Lake Erie and its three basins 
1992; Volta et al. 2013). Ruffe can thrive in various habitats that differ in salinity, temperature, productivity and depth (Ogle 1998; Volta et al. 2013). In the Great Lakes region, ruffe first invaded the St Louis River Estuary in the western Lake Superior during the mid-1980s, and has now spread to northern Lake Michigan (Gutsch and Hoffman 2016). Its invasion caused considerable concern for managers owing to its competition with native benthivores, such as yellow perch (Kangur and Kangur 1996), its consumption of fish eggs and small fish (Winfield et al. 1996a), and its high fecundity with early maturation (Devine et al. 2000).

Golden mussels are native to fresh and brackish waters of mainland China. They have since been dispersed across the globe via ballast water (Ricciardi 1998) and invaded South America around 1989 (Boltovskoy et al. 2006b). Keller et al. (2011) identified some South American ports as "high-risk" for spread of golden mussel to the Great Lakes. The golden mussel's wide range of ecological tolerances will allow it to survive within much of North America fresh waters that are not suitable to Dreissena spp., such as lakes with low calcium concentrations, high temperatures, low oxygen levels, and those ecosystems considered to be highly polluted (Boltovskoy et al. 2006b; Karatayev et al. 2007a). Interestingly, golden mussels have many functional similarities with Dreissena mussels that have already colonized Lake Erie including size, filter-feeding rate, rapid growth, gregariousness, short life span, early sexual maturity, high fecundity with planktonic larvae, and attachment in high densities to hard substrates by means of strong byssal threads (Karatayev et al. 2007a, 2010). Thus, golden mussels are expected to have similar impacts on the invaded ecosystems as Dreissena spp. did in North America (Darrigran and Damborenea 2011; Ricciardi 1998).

Killer shrimp are native to the Ponto-Caspian region. They spread to Germany, the Netherlands and all major French rivers following the opening of the Rhine-Main-Danube canal in 1992, and also occur in several lakes across central and southern Europe (Rewicz et al. 2014). Recently, killer shrimp invaded the Baltic Sea (Šidagyte et al. 2017) and there is great concern that they will invade the Laurentian Great Lakes (Fusaro et al. 2016). Killer shrimp have multiple feeding modes and are capable of switching between shredding, grazing, collecting micro- and macro- algae, coprophagy and carnivory (Maazouzi et al. 2011; Mayer et al. 2009; Platvoet et al. 2009). They consume conspecifics as well as other amphipods, isopods, insect larvae, juvenile crayfish, fish eggs and even small fish (Dick et al. 2002; Krisp and Maier 2005; MacNeil et al. 2011; Taylor and Dunn 2017). Where killer shrimp have invaded, they have caused large declines in abundance of native macroinvertebrates (Rewicz et al. 2014).

\section{Ecopath with Ecosim (EwE)}

The food web model we used to simulate potential effects of AIS in this study was Ecopath with Ecosim (EwE). EwE is a freely available ecosystem modeling software (http://www.ecopath.org/index.php) used to construct a mass-balance trophic model (Ecopath) and simulate ecosystem time-dynamics under designed scenarios (Ecosim) (Christensen and Walters 2004). Details of the model can be found in Christensen and Walters (2004) and in Supplementary Materials (Zhang et al. 2016). Briefly, the Ecopath model is constrained by two mass-balance principles: (1) the consumption by a biomass pool (or a model group) must be no less than the sum of total production and unassimilated food by that model group, i.e., respiration cannot be negative; (2) the total production must be no less than the sum of fishery catch, predation, net migration, and biomass accumulation, i.e., ecotrophic efficiency ( $E E$, the fraction of the production that is used in the system and does not move directly to the detritus pool) cannot be greater than 1. At a minimum, Ecopath requires inputs of diet composition, fisheryinduced mortality (not applicable to the three potential invasive species; i.e., we didn't consider the potential bycatch of ruffe with commercially harvested fish), and three of the following four parameters for each model group: biomass $(B)$, production-to-biomass ratio $(P / B)$, consumption-to-biomass ratio $(Q / B)$, and EE. Mass-balance principles are then used to estimate the fourth parameter. Ecosim then runs the balanced Ecopath under external driving forces, such as time series of fishery harvest and nutrient loads. In Ecosim, primary production is calculated using MichaelisMenten relationships and phosphorus concentration, while consumer production is governed by a set of coupled differential equations that re-express the production equation of the Ecopath model as: 
$\frac{d B_{j}}{d t}=g_{j} \sum_{i} Q_{i j}-\sum_{k} Q_{j k}-\left(M_{j}+F_{j}+E_{j}-I_{j}\right) B_{j}$

where $d B_{j} / d t$ represents the biomass $\left(B_{j}\right)$ accumulation rate of group $j$ during time interval $t, g_{j}$ is the growth efficiency (production-to-consumption ratio), $M_{j}$ is the natural mortality rate from sources other than predation (i.e., disease), $F_{j}$ is fishing mortality rate, $E_{j}$ is emigration rate, and $I_{j}$ is immigration rate. The two summations are estimates of consumption rate $Q$, with $Q_{i j}$ expressing the total consumption by group $j$ on prey $i$, and $Q_{j k}$ expressing the total predation by all predators $k$ on group $j$ (e.g., predation mortality on group $j$ ). In Ecosim, consumption $\left(Q_{i j}\right)$ of predator $j$ on prey $i$ was determined by:

$Q_{i j}=\frac{a_{i j} \times v_{i j} \times B_{i} \times B_{j} \times S_{i j} \times M_{i j} \times T_{i} \times T_{j} / D_{j}}{v_{i j}+v_{i j} \times T_{i} \times M_{i j}+a_{i j} \times M_{i j} \times B_{j} \times S_{i j} \times T_{j} / D_{j}}$

where $a_{i, j}$ is search rate on prey species $i$ by predator species $j, S_{i j}$ is user-defined seasonal or long term forcing effects, $M_{i j}$ is a mediation forcing effect (see below), $T_{i}$ is the relative feeding time of prey $i, T_{j}$ is the relative feeding time of predator $j$, and $D_{j}$ is the effect of handling time as a limit to consumption rate. The consumption is based on the 'forage arena' concept, where prey are divided into vulnerable and invulnerable components (Ahrens et al. 2011), and $v_{i j}$ is the vulnerability coefficient (i.e., transfer rate) between these two components. High vulnerability coefficients indicate high prey vulnerability to predators. Relative feeding time is a component of the foraging arena concept for the Ecopath with Ecosim model. Increases in relative feeding time will increase total consumption, but with a penalty of increased mortality rates.

\section{Lake Erie food web model}

We modified an existing EwE model for Lake Erie (Zhang et al. 2016, standard version 6.3.909.0) to predict the potential effects of the three potential benthic invaders on the Lake Erie food web. The Lake Erie food web model consisted of 47 model groups including birds, fish, benthos, zooplankton, phytoplankton, protozoa, bacteria, and detritus (Table 1). The model was mass balanced using data from 1999-2001 (Tables S1-S5 in Online Resource 1) and calibrated using observed time series of 14 trophic groups from 1999-2010 (see Zhang et al. 2016 for details).

\section{Parameter estimation of the three invasive species}

We estimated values for parameters of biomass (B), production to biomass ratio $(\mathrm{P} / \mathrm{B})$, consumption to biomass ratio $(\mathrm{Q} / \mathrm{B})$ and diets for the potential invaders in two ways. The first was to estimate values from related studies. The second method was to use values of functionally similar species that already reside in Lake Erie, such as Dreissena mussels for golden mussels and, Gammarus spp. for killer shrimp (Tables 2, 3, 4). The second approach assumes that the environmental tolerances of the invasive species are similar to those of the reference species in Lake Erie. This is reasonable because Lake Erie provides suitable habitat for golden mussels (Kramer et al. 2017; Ricciardi 1998) and killer shrimp (Kramer et al. 2017). We detail both approaches below.

Biomass $(B)$ We initiated pre-invasion biomass of the invaders at a low level to insure that they would not change the balanced food web in the original Ecopath model (Zhang et al. 2016), and that any rebalancing of Ecopath would only be for the newly introduced invasive species (Langseth 2012). Specifically, we set pre-invasion biomass for ruffe at 10 times lower than the Ecopath equilibrium biomass of round goby (Neogobius melanostomus), an invasive benthic fish in Lake Erie (Johnson et al. 2005). We set biomass of golden mussel at 100 times lower than the Ecopath equilibrium biomass of Dreissena mussels, and set killer shrimp biomass at 10 times lower than the Ecopath equilibrium biomass of Gammarus (Table 2).

Production to biomass ratio $(P / B) \mathrm{P} / \mathrm{B}$ ratio for ruffe was calculated from Brenton (1998). The P/B ratio for golden mussel was set to the value for invading zebra mussels in Lake Erie during 1993 (Johannsson et al. 2000), and for killer shrimp the ratio was set to the same value for the amphipods group (AMPH) used in Lake Erie EwE model (Table 2).

Consumption/Biomass $(Q / B)$ The $\mathrm{Q} / \mathrm{B}$ ratio for ruffe was set to 6.57 (Brenton 1998; Holker and Temming 1996). The Q/B value for golden mussels was determined by setting the P/Q to the same value as that for dreissenids, and for killer shrimp was set to the same value as that for amphipods in Lake Erie EwE model (Table 2). 
Table 1 Model groups in the Lake Erie EwE model excluding invasive Eurasian ruffe, killer shrimp and golden mussel

\begin{tabular}{|c|c|c|}
\hline Group & Symbols & Species \\
\hline \multirow[t]{2}{*}{ Waterbirds } & DCCM & Double-crested cormorant (Phalacrocorax auritus) \\
\hline & MERG & Red-breasted merganser (Mergus serrator), common merganser (M. merganser) \\
\hline \multirow[t]{22}{*}{ Fish } & $\begin{array}{l}\text { WAE-L, Y, } \\
\text { J, A }\end{array}$ & Walleye (Sander vitreus) larvae, YOY, juveniles (age 1-2) and adults (age $3+$ ) \\
\hline & $\begin{array}{l}\text { YEP-L, Y, J, } \\
\text { A }\end{array}$ & Yellow perch (Perca flavescens) larvae, YOY, juveniles (age 1), and adults (age $2+$ ) \\
\hline & GIZ & Gizzard shad (Dorosoma cepedianum) \\
\hline & RBT-Y, & Rainbow trout (Oncorhynchus mykiss) stocked yearlings \\
\hline & RBT-A & Rainbow trout (Oncorhynchus mykiss) adults \\
\hline & LWF & Lake whitefish (Coregonus clupeaformis) \\
\hline & BBT & Burbot (Lota lota) \\
\hline & WHP & White perch (Morone americana) \\
\hline & WHB & White bass (Morone chrysops) \\
\hline & SMB & Smallmouth bass (Micropterus dolomieu) \\
\hline & FWD & Freshwater drum (Aplodinotus grunniens) \\
\hline & ALW & Alewife (Alosa pseudoharengus) \\
\hline & LKT-Y & Lake trout (Salvelinus namaycush) stocked yearlings \\
\hline & LKT-A & Lake trout (Salvelinus namaycush) \\
\hline & RAS & Rainbow smelt (Osmerus mordax) \\
\hline & CMP & Common carp (Cyprinus carpio) \\
\hline & RGB & Round goby (Neogobius melanostomus) \\
\hline & SUK & $\begin{array}{l}\text { White sucker (Catostomus commersonii), quillback (Carpiodes cyprinus), bigmouth buffalo } \\
\text { (Ictiobus cyprinellus) }\end{array}$ \\
\hline & EMS & Emerald shiner (Notropis atherinoides), spottail shiner (N. hudsonius) \\
\hline & CAT & Channel catfish (Ictalurus punctatus), brown bullhead (Ameiurus nebulosus) \\
\hline & PanF & $\begin{array}{l}\text { Panfish including rock bass (Ambloplites rupestris), bluegill (Lepomis macrochirus), pumpkinseed } \\
\text { (L. gibbosus), white crappie (Pomoxis annularis), black crappie (P. nigromaculatus) }\end{array}$ \\
\hline & OthF & $\begin{array}{l}\text { Other fish including silver chub (Macrhybopsis storeriana), troutperch (Percopsis omiscomaycus), } \\
\text { logperch (Percina caprodes) }\end{array}$ \\
\hline \multirow[t]{7}{*}{ Benthos } & DREI & Zebra mussel (Dreissena polymorpha), quagga mussel (D. rostriformis bugensis) \\
\hline & AMPH & Amphipoda, Isopoda \\
\hline & CHIR & Chironomidae \\
\hline & OLIG & Oligochaeta \\
\hline & EPHE & Ephemeroptera \\
\hline & MOLL & Gastropoda, Sphaeriidae, Bivalvia \\
\hline & OthB & Other benthos mainly insect larvae \\
\hline \multirow[t]{4}{*}{ Zooplankton } & CLAD & Herbivorous cladocerans \\
\hline & COPE & Calanoida and Cyclopoida \\
\hline & PRED & Predatory cladocerans including Leptodora and Bythotrephes longimanus \\
\hline & ROTI & Rotifera \\
\hline Protozoa & PROT & Ciliates and heterotrophic flagellates \\
\hline Bacteria & BACT & Bacteria \\
\hline \multirow[t]{3}{*}{ Phytoplankton } & $\mathrm{PICO}$ & Picoplankton \\
\hline & EDIB & Edible algae mainly Chlorophyta, Cryptophyta, Bacillanophyta \\
\hline & INED & Inedible algae mainly Cyanophyta \\
\hline Detritus & DETR & Suspended and sediment detritus \\
\hline
\end{tabular}


Table 2 Ecopath parameter values (initial and equilibrium biomass, production to biomass (P/B), consumption to biomass (Q/B), other mortality, and trophic level for the three simulated invasive species

\begin{tabular}{llll}
\hline & Eurasian ruffe & Golden mussel & Killer shrimp \\
\hline Reference model groups & Round goby & Dreissenids & Amphipods \\
Initial biomass $\left(\mathrm{kg} \mathrm{ha}^{-1}\right)^{\mathrm{a}}$ & 1.6 & 31.8 & 0.8 \\
Equilibrium biomass $\left(\mathrm{kg} \mathrm{ha}^{-1}\right)^{\mathrm{b}}$ & $2.5-12.0$ & $304-4402$ & $1.55-3.99$ \\
P/B & $0.831^{\mathrm{c}}$ & $4.4^{\mathrm{d}}$ & $4.35^{\mathrm{d}}$ \\
Q/B & $6.57^{\mathrm{c}}$ & $20.28^{\mathrm{d}}$ & $23.02^{\mathrm{d}}$ \\
Other mortality $^{\mathrm{e}}$ & 0.05 & 0.2 & 0.07 \\
Trophic Level $^{\mathrm{b}}$ & 3.0 & 2.1 & 3.05 \\
\hline
\end{tabular}

${ }^{\mathrm{a}}$ Downscaled Ecopath biomass of reference model groups

${ }^{\mathrm{b}}$ Indicates values from the balanced Ecopath model

${ }^{\mathrm{c}}$ Brenton (1998); d. same as those for reference model groups

${ }^{\mathrm{e}}$ Set up by this study

Table 3 Fractional composition of diets (by weight) of the three nonindigenous species considered herein; Eurasian ruffe (RUF), golden mussel (GDML) and killer shrimp (KSHP). See Table 1 for the meanings of prey names

\begin{tabular}{llllll}
\hline RUF prey & RUF $^{\mathrm{a}}$ & GDML prey & GDML $^{\mathrm{b}}$ & KSHP prey & KSHP \\
\hline AMPH & 0.068 & PROT & AMPH & 0.500 \\
CHIR & 0.708 & BACT & 0.045 & CHIR & 0.300 \\
EPHE & 0.133 & PICO & 0.066 & EPHE & 0.010 \\
OthB & 0.031 & EDIB & 0.058 & OthB & 0.190 \\
CLAD & 0.042 & INED & 0.237 & & \\
COPE & 0.018 & DETR & 0.049 & & \\
\hline
\end{tabular}

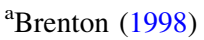

' Reference to dreissenids' diet

${ }^{c}$ Dick et al. (2002), Devin et al. (2001), Krisp and Maier (2005) and Pimentel (2005)

Diet composition Diets of ruffe in Lake Erie were assumed to be similar to those reported for ruffe in the St. Louis River Estuary, Lake Superior (Fullerton et al. 1998; Ogle et al. 1995). Diet of golden mussels was assumed to be the same as that of dreissenids (Boltovskoy et al. 2009; Karatayev et al. 2010; Sylvester et al. 2005). Studies have shown that killer shrimp can effectively decrease native and invasive Gammarus spp. (Dick et al. 2002; Gergs and Rothhaupt 2008), and cause considerable declines in the whole macroinvertebrate fauna in the Netherlands and France (Devin et al. 2001; Krisp and Maier 2005; Pimentel 2005). Thus, the diets of killer shrimp were set to include amphipods, mayflies, chironomids and other benthos, and the fractional composition of prey in diets was proportional to their biomass (Table 3). Diet fractions of new invasive species in their predator diets are usually unknown during the invading period. We applied the fractional diet composition of predators for the reference species as for the AIS, and reduced them by the same scalars (i.e., 10, 100, and 10 times lower for ruffe, golden mussel and killer shrimp, respectively) that we used to decrease initial biomass as showed in Table 4.

\section{Simulation scenarios}

Using the existing Lake Erie model as a starting point, we developed three new EwE models with the differences being only which invader was going to 
Table 4 Fractional composition of Eurasian ruffe (RUF), golden mussel (GDML) and killer shrimp (KSHP) in diets of their predators

\begin{tabular}{lclllr}
\hline RUF predator & RUF $\left(\times 10^{-3}\right)$ & GDML predator & GDML $\left(\times 10^{-4}\right)$ & KSHP predator & KSHP $\left(\times 10^{-3}\right)$ \\
\hline DCCM & 7.70 & MERG & 0.05 & YEP_Y & 4.50 \\
MERG & 3.30 & YEP_Y & 0.02 & YEP_J & 3.70 \\
WAE_J & 6.40 & YEP_J & 3.91 & YEP_A & 0.70 \\
WAE_A & 7.00 & YEP_A & 2.36 & LWF & 20.90 \\
YEP_J & 5.80 & LWF & 8.15 & WHP & 10.70 \\
YEP_A & 5.00 & BBT & 0.89 & WHB & 3.80 \\
RBT_A & 0.70 & WHP & 0.57 & FWD & 4.69 \\
BBT & 14.10 & FWD & 3.60 & CLW & 1.45 \\
SMB & 38.40 & CMP & 35.80 & RGB & 9.65 \\
LKT_A & 13.90 & RGB & 46.60 & CAT & 0.02 \\
SUK & 1.53 & CAT & 9.67 & PanF & 1.81 \\
CAT & 22.00 & & & OthF & 25.00 \\
PanF & 10.00 & & & 2.70 \\
\hline
\end{tabular}

See Table 1 for the meanings of predator names. Values were downscaled diet composition of predators on the reference model groups

invade. We used the approach of Zhang et al. (2016) to simulate the introductions of each invasive species, wherein the initial biomass for invasive species is set at low values in Ecopath with high fishing mortality (Table 2). In Ecosim, the timing of population growth was controlled by removing the fishing mortality (implemented as an artificial harvest function for AIS) in model year 2015 .

\section{Mediation function}

Similar to the dreissenid mussel invasion, we anticipated a large increase in golden mussel biomass if they establish in Lake Erie. The mediation function helps prevent unrealistically high proportions of golden mussels in fish diets and represents low efficiency in consumption of golden mussels by fish groups that cannot crack the shells (Fig. 2a, Kao et al. 2014). This function was set such that, the consumption efficiency on golden mussels decreased by up to $60 \%$ as golden mussel biomass increased (Botts et al. 1996). To reflect the field observations that mussels increased benthos biomass (such as Ephemeroptera and chironomids, but not oligochaetes) by providing shelter (Karatayev et al. 2010), we also applied this function on those benthic groups to decrease their predation mortalities. We used a second mediation function that (a)

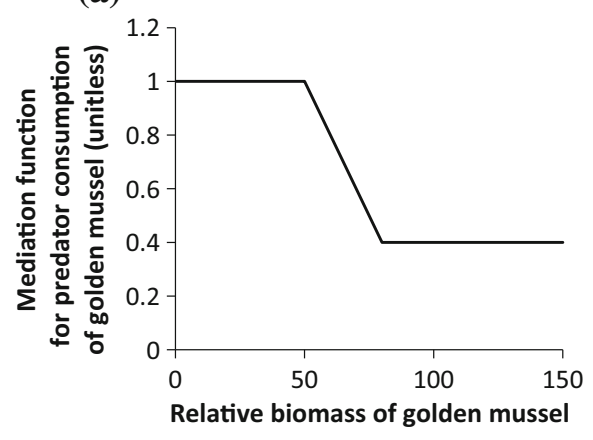

(b)

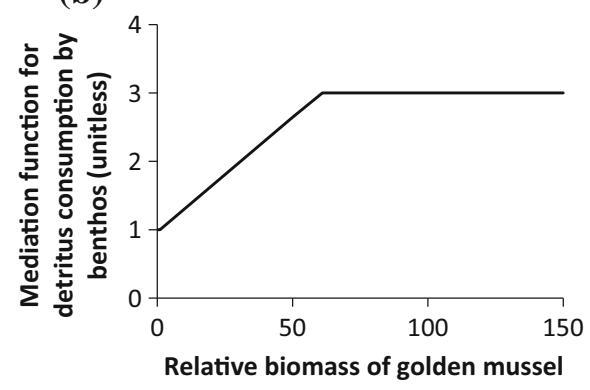

Fig. 2 Mediation functions used in Ecosim to adjust the consumption affected by golden mussel invasion for a predators feeding on golden mussel and $\mathbf{b}$ benthos feeding on detritus. The initial biomass of golden mussel in the Ecopath model was equal to 1 on the $\mathrm{x}$-axis. Note differences in $\mathrm{Y}$-axis scale among figures 
replicated the observation that mussels can increase detritus availability to the benthos through bio-deposition by up to 3 times (Fig. 2b) (Gergs and Rothhaupt 2008; Karatayev et al. 2010).

\section{Sensitivity analysis of vulnerability}

In EwE, the availability of prey $i$ to a predator $j$ is controlled by the vulnerability coefficient, $v_{i, j}$, between available and unavailable prey pools. Vulnerability of potential invasive species introduced into a new ecosystem is rarely known. Thus, we did a simple sensitivity analysis by varying the vulnerability of prey to the invasive species (PreyV) and vulnerability of invasive species to their predators (AISV), while keeping all other parameters the same. Expanding on the value ranges used in Zhang et al. (2016), the AISV was set to $1,2,10,20$ and 40 while keeping PreyV $=40$, and the PreyV was set to 2, 20, and 40 while AISV was held constant at 2 . The value of 2 is the default value in Ecosim for all vulnerabilities, and will maintain mass balance from the Ecopath equilibrium without any disturbance. Prey vulnerability values lower than 2 will decrease their vulnerability to predators, while values greater than 2 will increase their vulnerability.

\section{Food web responses}

We ran all simulations from 1999 to 2015 while keeping the potential invaders at a low biomass via an artificial harvest function. Following this initial period, we eliminated harvest on the potential invaders and ran the simulation for an additional 120 years to allow biomass of the invasive species to increase and reach a new equilibrium. Food web responses were reported as the average change in biomass for each group, which was calculated as:

$\frac{B_{i, \text { invasive }}-B_{i, \text { base }}}{B_{i, \text { base }}} \times 100$

where $B_{\text {,invasive }}$ is the average biomass of model group $i$ for the last 10 simulation years with a potential invasive species, $B_{i, \text { base }}$ is the average biomass of model group $i$ for the last 10 simulation years without a potential invasive species. A change of $20 \%$, or even $10 \%$ in fish production may seem large to fishery managers, but may not be detectable in the field because of sampling error and inherent variability in fish population dynamics (Kitchell et al. 2000). Thus, we defined a change in species biomass of $>25 \%$ as being significant in response to an invasive species introduction. If the response was $<25 \%$, then we conservatively considered it to be non-significant.

We compared some model parameter values for ruffe, killer shrimp and golden mussel, including P/B, $\mathrm{Q} / \mathrm{B}$, predation mortality and relative feeding time for invasive species at equilibrium, to parameter values for the invasive species' corresponding reference groups. Higher values of $\mathrm{P} / \mathrm{B}$ and $\mathrm{Q} / \mathrm{B}$ indicate higher growth rate and consumption rate. Higher predation mortality indicates higher predation loss. Higher values of relative feeding time close to the maximum value (2) indicate strong food limitation and more exposure to predators.

Relationship between invasive species biomass and their ecological impacts

To examine the relationships between AIS biomass and their food web impacts, for each AIS, we selected one prey group, one predator group, and one group indirectly affected by the AIS. We chose the groups that showed large changes $(>25 \%)$ in response to AIS. AIS ecological impacts were measured as the change in model group biomass relative to their baseline biomass levels without AIS present as AIS biomass increased, and fitted statistically significant regressions to indicate the trends.

\section{Results}

Invasive species biomass

Over the range of vulnerabilities tested, killer shrimp biomass was the least sensitive to variation in prey vulnerabilities, while golden mussel biomass was highly responsive to increases in prey vulnerability (Fig. 3). Golden mussel biomass was the least sensitive to increases in vulnerability to predators, while ruffe biomass was most sensitive to predator vulnerability, with killer shrimp biomass being intermediate in sensitivity (Fig. 3). Since AIS biomass leveled off after vulnerability to predators of AISV $=10$, we presented our results of AIS population growth and 

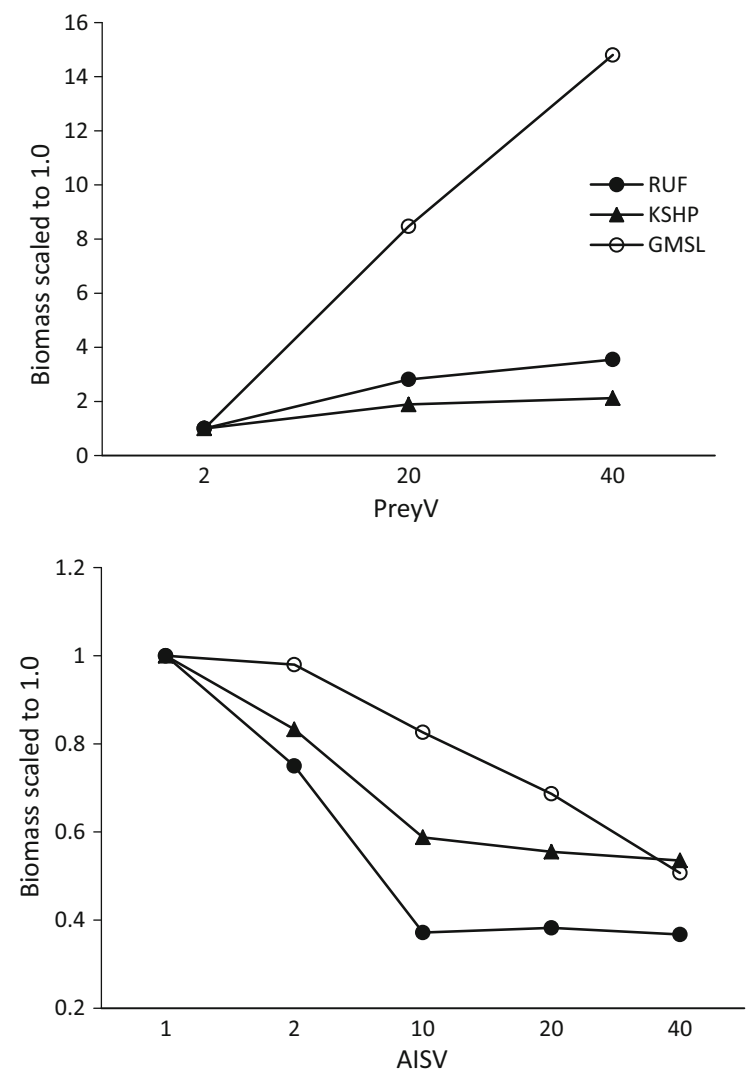

Fig. 3 Sensitivity of invasive species (AIS) biomass to variable prey vulnerability to AIS (PreyV) and AIS vunerability to predators (AISV). Invasive species biomass in the top figure was scaled to the biomass under a scenario of PreyV $=2$. Invasive species biomass in bottom figure was scaled to the biomass under a scenario of AISV $=1$. Note differences in $\mathrm{Y}$-axis scale among figures

impact for the range of predator vulnerabilities from 1 , 2, and 10, and prey vulnerabilities from 2, 20 and 40 .

All three invasions reached equilibrium in the Ecosim simulations within 15-25 years (assuming a starting year of 2015), with ruffe taking the longest time to reach equilibrium (Fig. 4). The treatment (AISV1Prey40), which had the lowest vulnerability to predation and highest prey vulnerability, resulted in the highest equilibrium biomass of invasive species, while the treatment (AISV2Prey2), which had the lowest prey vulnerability, resulted in the lowest equilibrium biomass. In general, biomass of the three invasive species decreased as their vulnerability to their predators (AISV) increased when their prey vulnerability was held constant (Fig. 4). Their biomass also decreased as prey vulnerability decreased from 40 to 2 while AIS vulnerability to predators was held constant. Over the range of vulnerability scenarios, killer shrimp biomass varied from 1.55 to $3.99 \mathrm{~kg} \mathrm{ha}^{-1}$, ruffe biomass varied from 2.5 to $12.0 \mathrm{~kg} \mathrm{ha}^{-1}$, and golden mussel biomass varied from 287 to $4338 \mathrm{~kg} \mathrm{ha}^{-1}$.

Food web responses

\section{Ruffe impacts}

Simulated ruffe invasion had variable but relative minor $(<25 \%$ change) effects on most trophic groups in the Lake Erie food web with a few notable exceptions (Fig. 5, Table S6 in Online Resource 1). At biomass levels $\geq 4.5 \mathrm{~kg} \mathrm{ha}^{-1}$, ruffe invasion had a significant ( $>25 \%$ change from baseline) positive effect on piscivorous smallmouth bass, which increased by as much as $70 \%$ above the baseline scenario with no ruffe (Fig. 5). Ruffe invasion had negative effects on biomass of two omnivorous fishes: white perch Morone americana declined by as much as $66 \%$ below baseline and freshwater drum Aplodinotus grunniens declined by $25 \%$ (at the highest ruffe biomass $=12 \mathrm{~kg} \mathrm{ha}^{-1}$ ). Significant negative effects on lower trophic levels were found only for Ephemeroptera biomass (EPHE), which decreased by $>25 \%$ for all ruffe biomass scenarios except the lowest biomass scenario and by as much as $77 \%$ below baseline at the highest ruffe biomass.

\section{Killer shrimp impacts}

Simulated invasion of killer shrimp also had relatively minor effects on the Lake Erie food web (Fig. 6, Table S7 in Online Resource 1). At high biomass levels $\left(4 \mathrm{~kg} \mathrm{ha}^{-1}\right)$, killer shrimp had positive effects on planktivorous gizzard shad Dorosoma cepedianum biomass, but negative effects on omnivorous white perch which declined by $56 \%$ from baseline. Interestingly, white perch biomass increased $44 \%$ from baseline at intermediate killer shrimp levels (3.0 $\mathrm{kg} \mathrm{ha}^{-1}$ ), when the vulnerability of killer shrimp to its predator was high $(\mathrm{AISV}=10)$. Biomass of other omnivorous fish showing significant decreases from baseline were white bass Morone chrysops (at killer shrimp biomass $=2.4 \mathrm{~kg} \mathrm{ha}^{-1}$ ) and freshwater drum (at killer shrimp biomass $=4 \mathrm{~kg} \mathrm{ha}^{-1}$ ). Biomass of two benthic groups declined below baseline at 
Fig. 4 Simulated response of invasive species biomass to different vulnerability treatments. 'AISV1-V10' indicates increasing vulnerability of the invasive species to predators. 'PreyV2-V40' indicates increasing vulnerability of prey to the invasive species. Note differences in Y-axis scale among figures
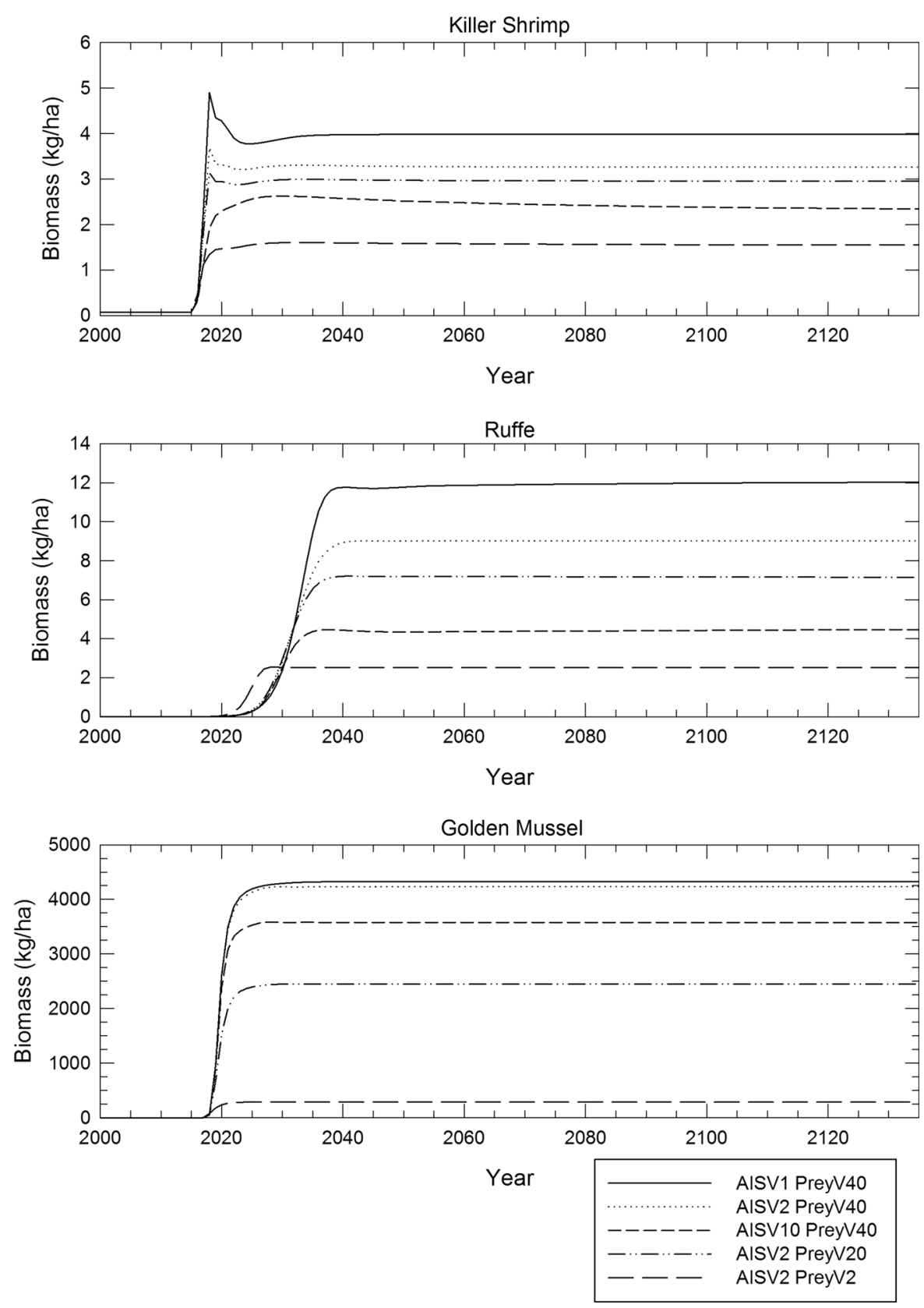

intermediate and high killer shrimp biomass levels, including amphipods (AMPH, at killer shrimp biomass $\geq 2.4 \mathrm{~kg} \mathrm{ha}^{-1}$ ) and Ephemeroptera (EPHE, at killer shrimp biomass $=4 \mathrm{~kg} \mathrm{ha}^{-1}$ ). For the most part, piscivores, planktivores, and plankton were unaffected by killer shrimp.

\section{Golden mussel impacts}

Golden mussels had significant effects on most trophic groups when golden mussel biomass was $\geq 2431 \mathrm{~kg} \mathrm{ha}^{-1}$ (Fig. 7, Table S8 in Online Resource 1). The greatest positive effects occurred for some piscivores, most omnivores (with the exception of juvenile yellow perch) and most benthic invertebrates (with the exception of a negative effect 
Fig. 5 Simulated biomass web groups to the invasion by ruffe in Lake Erie.

Numbers in parentheses are equilibrium biomass $\left(\mathrm{kg} \mathrm{ha}^{-1}\right)$ of ruffe under each scenario. Note differences in Y-axis scale among figures responses of selected food

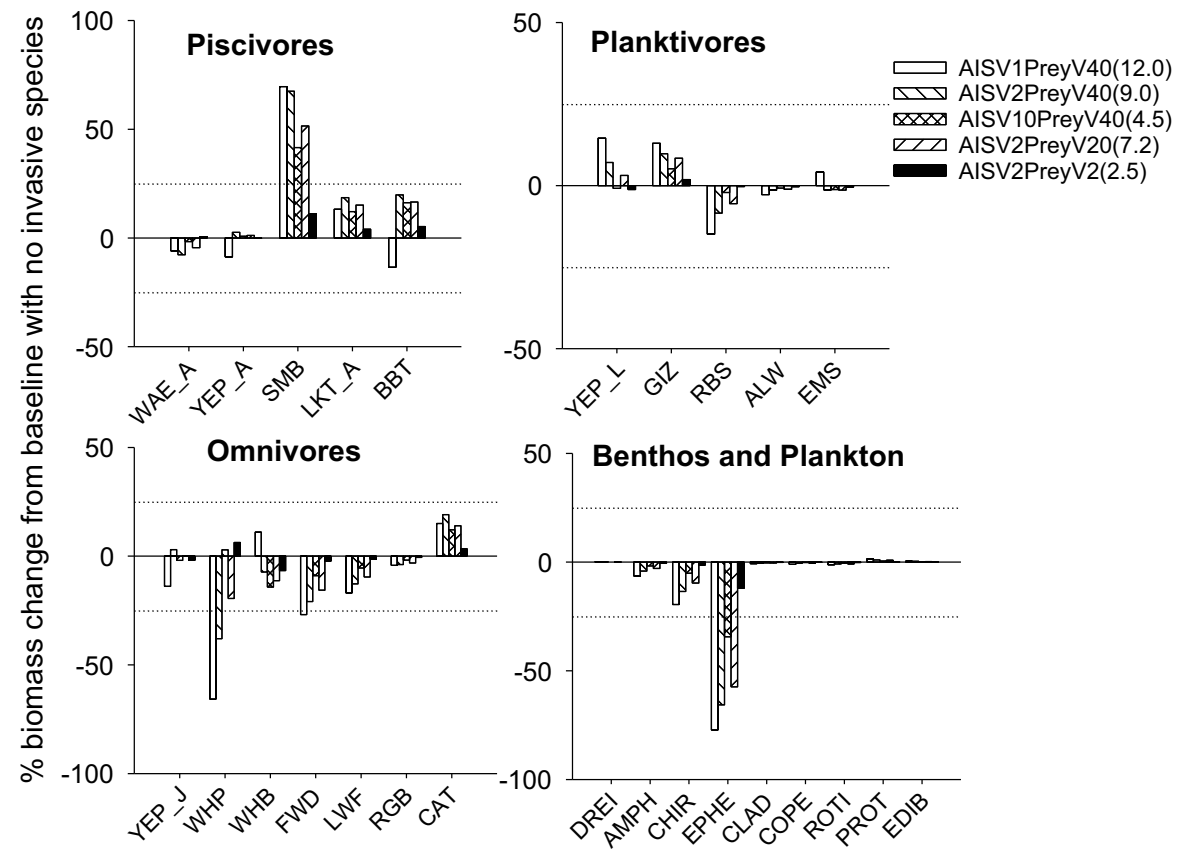

Fig. 6 Simulated biomass responses of select food web groups to the invasion by killer shrimp. Numbers in parentheses are equilibrium biomass $\left(\mathrm{kg} \mathrm{ha}^{-1}\right)$ of killer shrimp under each scenario. Note differences in Y-axis scale among figures
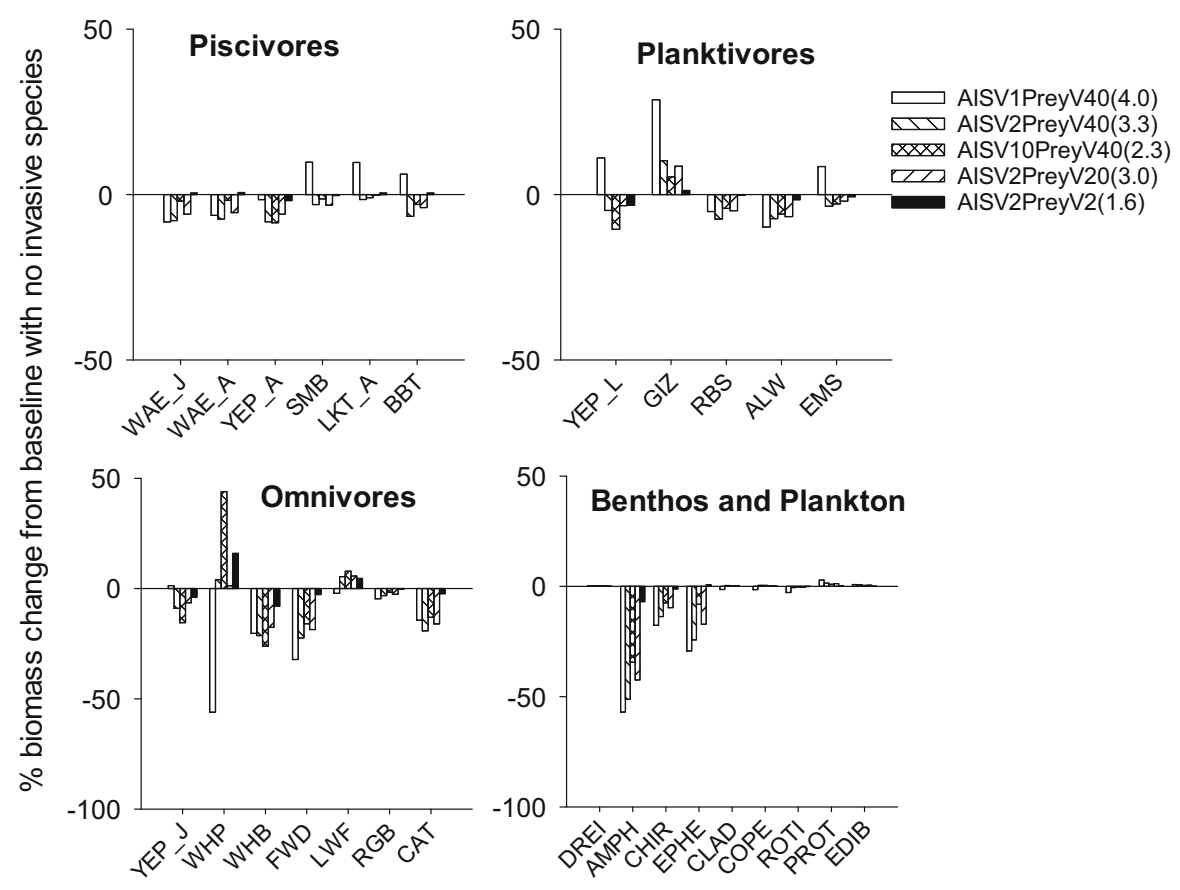

on dreissenids). The greatest negative effects consistently occurred for planktivores and plankton at all golden mussel biomass values $\geq 2430 \mathrm{~kg} \mathrm{ha}^{-1}$ (Fig. 7). For piscivores, the greatest positive effects were for smallmouth bass across all biomass levels of golden mussel with biomass increases above baseline of up to $225 \%$. Other positive effects occurred for lake trout Salvelinus namaycush and burbot Lota lota (at intermediate mussel biomass $=3583 \mathrm{~kg} \mathrm{ha}^{-1}$ ) when mussel vulnerability to their predators was high 
Fig. 7 Simulated biomass responses of select food web groups to the invasion by golden mussels. Numbers in parentheses are equilibrium biomass $\left(\mathrm{kg} \mathrm{ha}^{-1}\right)$ of golden mussels under each scenario. Note differences in $\mathrm{Y}$-axis scale among figures
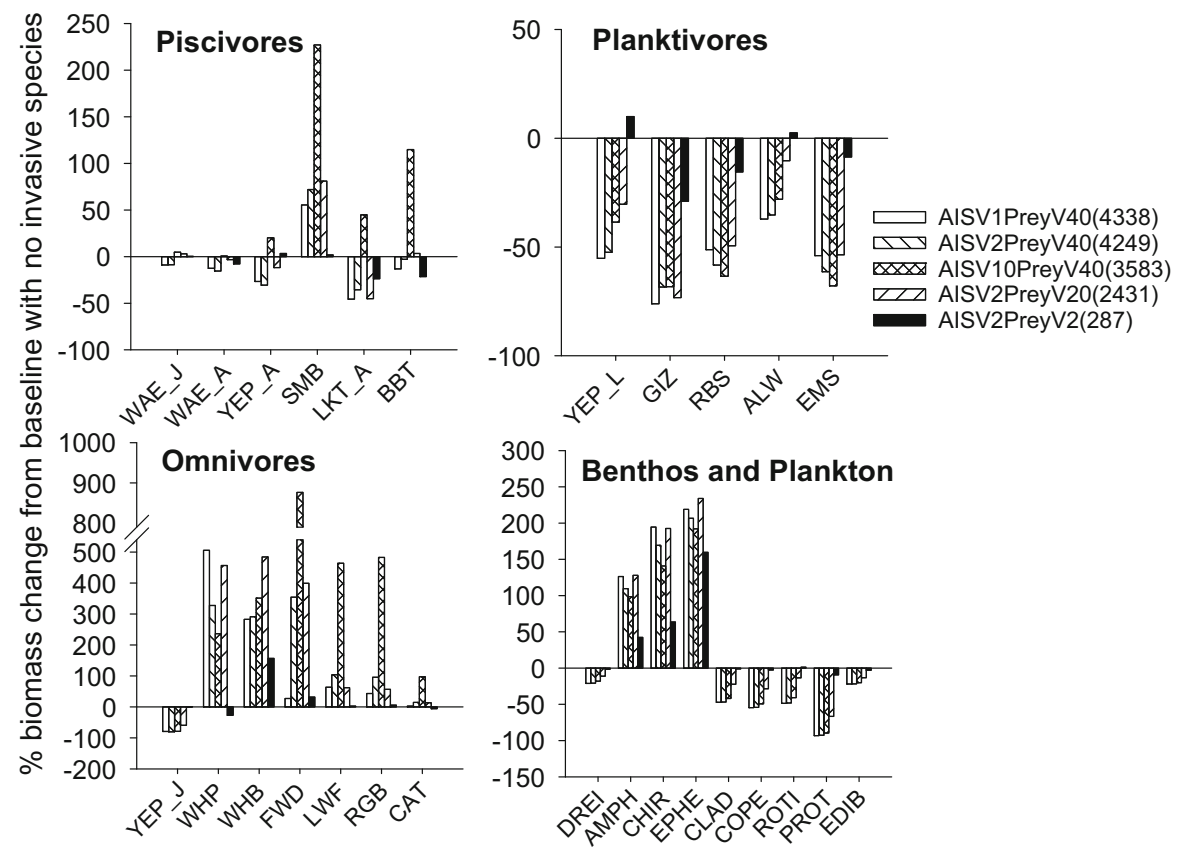

(AISV $=10$ ). When mussel vulnerability was low (i.e., AISV1 or 2), there was a negative effect on lake trout with as much as a $45 \%$ decline below baseline at high golden mussel biomass levels.

The EwE model parameter value for production to biomass $(\mathrm{P} / \mathrm{B})$, consumption to biomass $(\mathrm{Q} / \mathrm{B})$, predation mortality and relative feeding time all differed from their corresponding reference species after reaching equilibrium in the vulnerability scenario simulations (Table 5). All P/B values of the three invasive species, and $\mathrm{Q} / \mathrm{B}$ values of golden mussels and killer shrimp were lower than their corresponding reference groups, and lower than their initial values. $\mathrm{Q} / \mathrm{B}$ of ruffe was higher than for round goby at the end of the simulations. Golden mussel's predation mortality was slightly higher than that of dreissenid mussels. Killer shrimp had a lower value for predation mortality than that of the resident amphipod group. Ruffe experienced a much higher predation mortality $\left(0.71\right.$ year $\left.^{-1}\right)$ than did round goby $\left(0.33\right.$ year $\left.^{-1}\right)$. Relative feeding time values were 2 for golden mussels, and almost always 2 for killer shrimp except in scenarios of high predation (i.e., AISV $=10$ ), but never reached 2 for ruffe. Comparison of parameter values among the 3 invasive species indicated that killer shrimp had the highest values for $\mathrm{P} / \mathrm{B}, \mathrm{Q} / \mathrm{B}$ and predation mortality, while golden mussel had the lowest values for $\mathrm{Q} / \mathrm{B}$ and predation mortality, but the highest value for relative feeding time.

Relationship between invasive species biomass and their ecological impacts

Biomass increases of AIS had monotonic and nonmonotonic effects on selected prey and predator biomass groups. For ruffe, killer shrimp and golden mussel, we respectively show Ephemeroptera (EPHE), amphipods (AMPH), and Protozoa (PRO) as prey groups; smallmouth bass (SMB), white perch (WPH), and round goby (RDG) as direct predators; and WHP, gizzard shad (GIZ) and SMB as indirectly affected groups (Fig. 8). Ruffe impacts changed monotonically with ruffe biomass for WPH (linear decrease), EPHE (non-linear decrease) and SMB (non-linear increase) (Fig. 8). Killer shrimp impacts changed monotonically for AMPH (nonlinear decrease) and GIZ (linear increase), but were lowest for WPH at relatively intermediate killer shrimp biomass (Fig. 8). Similarly, golden mussel impacts on PRO changed monotonically with increasing mussel biomass, but impacts on RDG and SMB were highest at intermediate levels of golden mussel biomass and regression relationships were not significant. 
Table 5 EwE model parameter values (mean $\pm 1 \mathrm{SD}$ ) at the end of all scenario simulations for the three benthic invasive species and their reference groups in the Lake Erie food web

\begin{tabular}{|c|c|c|}
\hline Parameter & $\begin{array}{l}\text { AIS } \\
\text { Eurasian ruffe }\end{array}$ & $\begin{array}{l}\text { Reference group } \\
\text { Round goby }\end{array}$ \\
\hline P/B $\left(\right.$ year $\left.^{-1}\right)$ & $0.77 \pm 0.02$ & $0.89 \pm 0$ \\
\hline $\mathrm{Q} / \mathrm{B}\left(\right.$ year $\left.^{-1}\right)$ & $6.1 \pm 0.16$ & $5.84 \pm 0$ \\
\hline Predation mortality $\left(\right.$ year $^{-1}$ ) & $0.71 \pm 0.03$ & $0.33 \pm 0$ \\
\hline Relative feeding time (unitless) & $1.58 \pm 0.27$ & $1 \pm 0$ \\
\hline Total prey biomass $\left(\mathrm{kg} \mathrm{ha}^{-1}\right)$ & 52 & \\
\hline Parameter & $\begin{array}{l}\text { AIS } \\
\text { Killer shrimp }\end{array}$ & $\begin{array}{l}\text { Reference group } \\
\text { Amphipods }\end{array}$ \\
\hline $\mathrm{P} / \mathrm{B}\left(\right.$ year $\left.^{-1}\right)$ & $3.48 \pm 0.37$ & $5.23 \pm 0.52$ \\
\hline $\mathrm{Q} / \mathrm{B}\left(\right.$ year $\left.^{-1}\right)$ & $18.42 \pm 1.97$ & $27.68 \pm 2.73$ \\
\hline Predation mortality (year ${ }^{-1}$ ) & $3.36 \pm 0.38$ & $4.83 \pm 0.63$ \\
\hline Relative feeding time (unitless) & $1.92 \pm 0.17$ & $0.59 \pm 0.17$ \\
\hline Total prey biomass $\left(\mathrm{kg} \mathrm{ha}^{-1}\right)$ & 27 & \\
\hline Parameter & $\begin{array}{l}\text { AIS } \\
\text { Golden mussels }\end{array}$ & $\begin{array}{l}\text { Reference group } \\
\text { Dreissenid mussels }\end{array}$ \\
\hline $\mathrm{P} / \mathrm{B}\left(\right.$ year $\left.^{-1}\right)$ & $0.78 \pm 0.07$ & $1.39 \pm 0$ \\
\hline $\mathrm{Q} / \mathrm{B}\left(\right.$ year $\left.^{-1}\right)$ & $3.59 \pm 0.33$ & $6.41 \pm 0$ \\
\hline Predation mortality $\left(\right.$ year $^{-1}$ ) & $0.07 \pm 0.07$ & $0.02 \pm 0$ \\
\hline Relative feeding time (unitless) & $2 \pm 0$ & $1 \pm 0$ \\
\hline Total prey biomass $\left(\mathrm{kg} \mathrm{ha}^{-1}\right)$ & $1000+$ detritus & \\
\hline
\end{tabular}

\section{Discussion}

Simulated equilibrium biomass of the invasive species

Our simulations of potential biomass of the three invasive species in Lake Erie were within the ranges observed for those species in other waters. In its native range, ruffe densities vary widely from $0.26 \mathrm{~kg} \mathrm{ha}^{-1}$ to $210 \mathrm{~kg} \mathrm{ha}^{-1}$ (Kováč 1998), while in in Lakes Superior's St Louis River Estuary, ruffe densities peaked at 1892 individuals $\mathrm{ha}^{-1}\left(\sim 32 \mathrm{~kg} \mathrm{ha}^{-1}\right.$ assuming an average mass of $17 \mathrm{~g}$ ) soon after establishment (Peterson et al. 2011). Killer shrimp biomass reported in European rivers were as high as $50-70 \mathrm{~kg} \mathrm{ha}^{-1}$ wet weight (Berezinal and Ďuriš2 2008). Golden mussel biomass was reported as high as $15,700 \mathrm{~kg} \mathrm{ha}^{-1}$ in Paraná River South America (Sylvester et al. 2007). Our modeled AIS obtained equilibrium biomass levels (2.5-12 $\mathrm{kg} \mathrm{ha}^{-1}$ for ruffe, $1.6-4 \mathrm{~kg} \mathrm{ha}^{-1}$ for killer shrimp, and $287-4338 \mathrm{~kg} \mathrm{ha}^{-1}$ for golden mussel) that were lower in Lake Erie than peak biomass levels observed elsewhere, but represent biomass averaged across all Lake Erie basins, and may be locally higher in the productive western basin than in the more oligotrophic eastern basin.

Characteristics of receiving ecosystems (e.g., food availability and predator abundance) and ecological processes (e.g., food competition and predation) could strongly affect the establishment and realized population biomass of an invasive species, and the response is likely unique to the invasive species. In our modeled food web, the biomass of prey available to the three benthic species, and to a lesser extent the predation mortality rate, also influenced their realized equilibrium biomass. By feeding on plankton at trophic level two, golden mussel accessed a larger prey biomass $\left(\sim 1000 \mathrm{~kg} \mathrm{ha}^{-1}\right)$ and reached a higher biomass level than was available to ruffe ( $52 \mathrm{~kg} \mathrm{ha}^{-1}$ prey biomass) or killer shrimp (27 $\mathrm{kg} \mathrm{ha}^{-1}$ prey biomass) that fed on benthos at a higher trophic level (level three). Calculated predation mortality rates also were lower for 
(a)

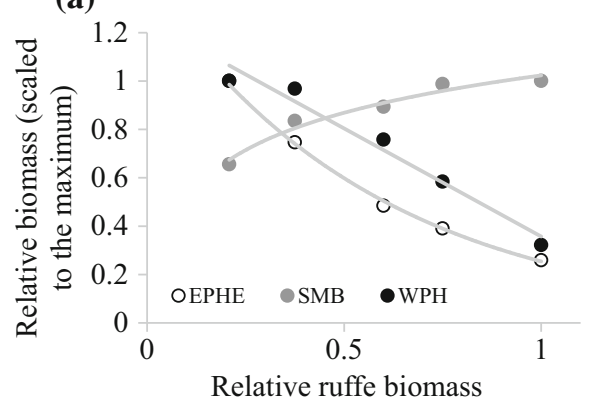

(b)
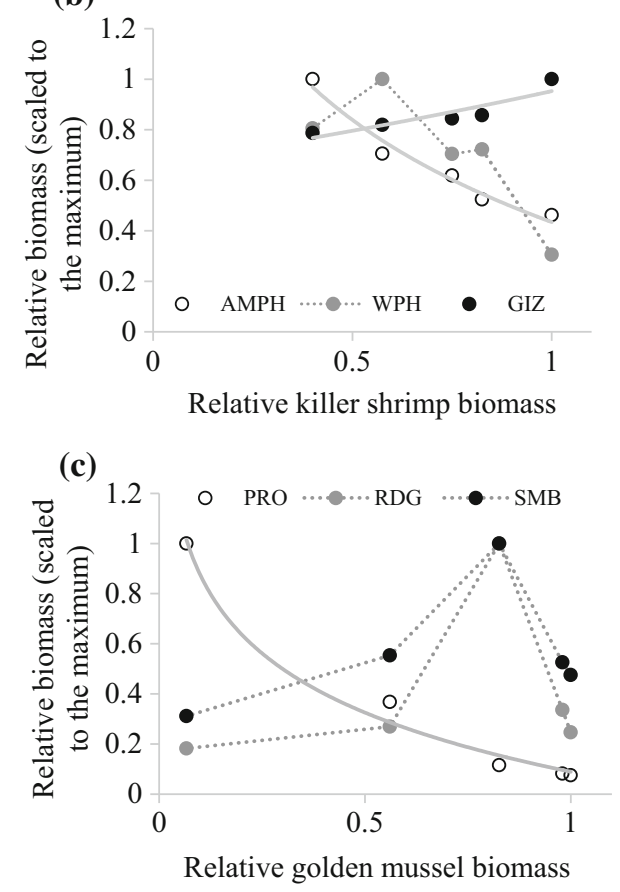

Fig. 8 Relationship between biomass of AIS and other model groups. Biomass of each group were scaled to its maximum. Solid lines are statistical regressions and indicate monotonic trend. The dashed lines link the data points and indicate nonmonotonic trends

golden mussel (0.07) and ruffe (0.71) than for killer shrimp (3.36) (Table 5).

In our simulations, the biomass of all three AIS was more sensitive to uncertainty in prey vulnerability than to uncertainty in predation pressure, especially for golden mussels. When prey vulnerability was high, golden mussel attained a biomass level comparable to, or even higher than dreissenid mussels. The highest total biomass of dreissenid and golden mussels simulated in our model was $6356 \mathrm{~kg} \mathrm{ha}^{-1}$, which was similar to the peak dreissenid biomass previously estimated in Lake Erie $\left(6750 \mathrm{~kg} \mathrm{ha}^{-1}\right)$ during early 2000 by Karatayev et al. (2014). The observed decrease in dreissenid mussels after the peak may be partially attributed to food limitations associated with their filtering activity (Karatayev et al. 2014). The higher prey vulnerabilities to golden mussels (2-40) compared to dreissenid mussels $(=1)$ in our model may be supported by (1) golden mussels having a much higher clearance rate (Pestana et al. 2009), and (2) being able to exploit food resources in habitats not available to dreissenid mussels in Lake Erie, such as in hypoxic waters of Lake Erie's central basin (Karatayev et al. 2007b; Patterson et al. 2005) that may comprise up to one-third of the total lake area (Zhou et al. 2013).

Ruffe and killer shrimp fed at higher trophic levels, experienced higher predation mortality and were more sensitive to predation than golden mussels. Lake Erie has abundant benthivorous and omnivorous fish (e.g., yellow perch, freshwater drum, lake whitefish Coregonus clupeaformis, catfish Ictaluridae spp.) that have adapted to increases in benthic-oriented energy pathways in response to the invasion by dreissenid mussels and round gobies (Ives et al. 2018). These benthivores likely would pose strong food competition with, and predation on ruffe and killer shrimp. Although the dreissenid invasion increased biomass of some benthic invertebrates through biodeposition, it also provided shelter and decreased their availability to predators (Burlakova et al. 2018).

Invasive species impacts on the Lake Erie food web

Our hypothesis that invasive species impacts on Great Lakes food webs were correlated with species biomass was well supported by our model simulations of ruffe impacts, especially for those significantly affected groups (changes $>25 \%$ ). However, our simulation results indicated that even at peak ruffe biomass, its impacts on many groups were relatively minor. These results are similar to observations in the St. Louis River estuary, where two decades after the ruffe first invaded there has not been any obvious negative impacts of ruffe on yellow perch or other fishes (Peterson et al. 2011). The immediate declines of yellow perch and other native fish populations in the St. Louis River following the ruffe invasion were more likely the result of fluctuations in natural population 
dynamics rather than interactions with ruffe (Bronte et al. 1998). Our model prediction of increased predator biomass (smallmouth bass) is consistent with findings from a study of ruffe invasion in a European lake where ruffe became a primary prey for other piscivorous fish and birds in the invaded ecosystem (Adams and Maitland 1998). Though Peterson et al. (2011) did not report increases in smallmouth bass abundance before and after a ruffe invasion in the St. Louis River estuary as our model predicted for Lake Erie, they did show that smallmouth bass remained abundant in the St Louis River even after ruffe established. Some model groups (e.g., white perch) in our simulation scenarios experienced positive or negative impacts with variable ruffe biomass as a result of the balance between predation (e.g., smallmouth bass and walleye) and food competition with forage fish for zooplankton and benthos. This dynamic underlines the importance of a food web approach in estimating invasive species effects.

Killer shrimp impacts on the simulated food web were correlated with biomass but were limited to a few species. Our model results showed killer shrimp had strong negative impacts on a few benthic prey groups, especially amphipods, but minor effects on omnivorous fish. Killer shrimp are well-documented predators of other benthic invertebrates (Dick et al. 2002; Haas et al. 2002; Hellmann et al. 2017; Macneil et al. 2013), and have caused elimination of local native Gammarus spp. (Macneil et al. 2013). In addition, killer shrimp's high predatory capacity was corroborated in functional response experiments with other native and invasive amphipods (Bollache et al. 2008; Bovy et al. 2015; Dodd et al. 2014). Less studied have been the positive effects of killer shrimp on a food web. Our results showed that killer shrimp had variable but positive effects on omnivorous white perch by serving as an additional food item. In Lake Balaton, Central Europe, Dikerogammarus spp. comprised up to $95 \%$ of the diets of European perch Perca fluviatilis ranging in size from 81 to $160 \mathrm{~mm}$ (Rezsu and Specziár 2006). In Grafham Water, England, invasive killer shrimp eliminated native Gammarus spp. and invasive Chelicorophium curvispinum, and became the dominant food in diets of brown trout Salmo trutta and rainbow trout (Madgwick and Aldridge 2011). However, there are few reports of changes in fish populations owing to killer shrimp invasion.
The simulated effects of golden mussels on the food web were positively associated with golden mussel biomass, and significant on plankton and planktivores, benthos and omnivores. Our model showed that golden mussel invasion decreased Dreissena mussel biomass, but not by a significant amount. If golden mussels use dreissenid mussels for settling habitat, their establishment would result in even lower biomass of dreissenid mussels owing to interference competition. Further, our model results agreed with predictions that golden mussel could decrease zooplankton, planktivorous fish, increase benthic macroinvertebrates, and molluscivorous fishes in invaded waters (Darrigran and Damborenea 2011; Karatayev et al. 2010; Ricciardi 1998).

\section{Relationship between invasive species biomass} and its ecological impacts

Invasive species biomass or abundance has been used as a predictor of the magnitude of invasive species' ecological impacts, assuming high AIS biomass/ abundance leads to high impacts, i.e. a monotonic relationship. For example, the "per capita effect" approach hypothesizes that abundance of invasive species is proportional to the impact magnitude (Dick et al. 2014; Laverty et al. 2017; Parker et al. 1999); i.e., there is a linear relationship between invasive species abundance and food web impacts. As another example, Kulhanek et al. (2011) developed a linear niche model to predict the occurrence and abundance of common carp (Cyprinus carpio) and assumed carp abundance was a surrogate of the relative severity of their impact. Yokomizo et al. (2009) argued that the relationship between invasive species abundance and managing the impact of the invasive (they define this as the "density-impact curve") may take on several non-linear forms (they define four general relationships), and errors in defining the curve can have significant consequences on the economics of management decisions. Moreover, Jackson et al. (2015) experimentally developed density-impact curves for an invasive fish (Pseudorasbora parva) and its impact on a simplified pelagic/benthic food web. They found both linear and nonlinear monotonic relationships and cautioned against assuming a linear relationship between invasive species density and impacts as this can lead to significant underestimates or overestimates of impacts. Results of our simulations are consistent 
with the underlying theory of density-impact curves with the relationship between density and impact taking both linear and nonlinear forms.

Studies of the non-monotonic relationships between AIS biomass and their impacts are rare. Jackson et al. (2015) showed a non-monotonic s-shaped relationship between the invasive fish and benthic invertebrate abundance, however, this was grouped into the non-linear relationship category and did not attract more attention. Our simulations showed monotonic and non-monotonic responses by several model groups to killer shrimp or golden mussel biomass. For example, round goby was mostly affected by intermediate levels of golden mussel biomass. The effects of golden mussel on round goby were highly influenced by mussel vulnerabilities (AISV) to round goby rather than by the simulated mussel equilibrium biomass.

Vulnerability in the Ecopath-Ecosim model integrates many characteristics of the recipient ecosystem that may affect food availability, including restrictions of predator or prey spatio-temporal distributions and activities through predation risk, habitat limitations, agonistic behavior, and physical transport (Ahrens et al. 2011). Thus, to predict ecological impacts of an AIS, the characteristics of the recipient ecosystem are critical to consider. This is supported by the metaanalysis by Kulhanek et al. (2011) on the impacts of 19 invasive species. Given the tremendous variation in the factors that may influence invasion success within ecosystems, Kulhanek et al. (2011) couldn't develop a predictive linear model for 18 out the 19 invasive species they selected. Only common carp had enough data, and the model developed for it had to include a term to reflect site-specific differences in initial conditions. This further confirms the importance of considering characteristics of the recipient ecosystems when predicting the ecological impacts of an invasive species.

Model uncertainties in the food web (EwE) model

There are several challenges associated with modeling invasive species impacts on a food web, especially for potential invaders that have not yet been introduced into a particular ecosystem. These challenges include, but are not limited to, uncertainties associated with diet composition (e.g., missing food web pathways), vulnerabilities of new species to predators, prey vulnerabilities to the new species, non-consumptive effects (i.e., aggressiveness, threat of predation), in addition to the usual uncertainties associated with the estimation of model input variables (biomass, production, diet composition), what species or functional groups to include, lack of spatial heterogeneity in the model, and lack of physical and chemical habitat conditions (e.g., water temperature, $\mathrm{pH}$, substrate composition) that may influence organism distribution, physiology, and behavioral interactions. Below we address each of these in turn.

Diet composition Diet of an invasive species is unknown prior to its introduction to a new ecosystem. Often, AIS diet information is used from other ecosystems where that species is a native and/or in ecosystems where the species has already invaded. This is a logical first step, but it may ignore new prey resources that become available. The ultimate consequence is that pathways for direct and indirect trophic effects may be missed by the food web simulation. In our case, we ignored predation on fish eggs and larvae by killer shrimp or ruffe, which may decrease the recruitment of lake whitefish (Casellato et al. 2007; Winfield et al. 1996b), common carp, or lake trout (Taylor, Dunn 2017) which deposit their eggs on substrates. Unlike round goby, ruffe are spiny-rayed fish and may be less favorable to piscivores. Thus, we may have overestimated the predation pressure on ruffe and underestimated its equilibrium biomass and ecological impacts. Nevertheless, many piscivores in Lake Erie are generalists and opportunists (Johnson et al. 2005), and may adapt to this new prey source, as has been observed on round gobies (Pothoven et al. 2017). Predator diet switch to ruffe also was reported in European waters (Ogle 1998).

Vulnerabilities In Ecosim, the "foraging arena theory" is used to represent the spatial and temporal restrictions on predator and prey interactions, and partitions each prey population into vulnerable and invulnerable population components (Ahrens et al. 2011). Trophic interactions take place in the restricted 'foraging arena', where vulnerable prey can be found and predation rates are dependent on (and limited by) exchange rates (or vulnerability coefficients) between these prey components. Vulnerability coefficients play an important role in determining equilibrium biomass and the ecological impacts of invasive species, which was especially demonstrated in golden mussel simulations. This parameter in EwE is usually estimated 
through fitting a model to a time-series of observed biomass data (Heymans et al. 2009). However, such time-series data do not exist for potential invasive species. Some methods to measure vulnerabilities have been attempted but none of them is satisfactory owing to the spatial, temporal and biological/taxonomic complexity of ecosystems (Ahrens et al. 2011). For example, sessile mussels filter the water column above their resting site, and prey vulnerability is highly affected by how fast algal and detritus prey are delivered to the bottom water, which is further influenced by physical water mixing, prey sinking rates, algal species, etc. In this study, we covered a range of potential values in an attempt to capture the uncertainty inherent in our model predictions.

Other factors There were several other factors not explicitly incorporated in our approach. First, there was no consideration of behavioral interactions and non-consumptive effects among competitors in our simulations. For example, golden mussels may settle on Dreissena mussels and compete for space, which may further decrease the biomass of dreissenids. Also, round goby has demonstrated aggressive behavior towards ruffe and other benthic competitors (Balshine et al. 2005; Church et al. 2017; Jůza et al. 2017), which might restrict ruffe's invasion and establishment. Secondly, positive effects by these three benthic invaders may have been overestimated for some fishes. For example, we predicted that biomass of lake whitefish and other benthivores that could eat golden mussel will increase significantly with golden mussel invasion, yet studies show that although lake whitefish can feed on dreissenid mussels and survive, their growth and body condition are low owing to the poor food quality of the mussels (Lumb and Johnson 2012; Pothoven and Madenjian 2008).

Lastly, we only simulated one invasive species at a time. Successful invasion of one species may assist or hinder the success of other invasive species (e.g., Simberloff and Von Holle 1999). For example, successful invasion of dreissenid mussels provided sufficient food and facilitated the establishment of invasive round goby (Vanderploeg et al. 2002). The invasion of killer shrimp may facilitate ruffe invasion by serving as prey, or golden mussel may facilitate killer shrimp invasion by providing mussels shelter and bio-deposits as prey. Future work should incorporate more mechanistic interactions into this or other model frameworks for more comprehensive prediction of potential impacts of invasive species.

Management implications

Based on a meta-analysis of data from the internet, peer-reviewed literature as well as expert judgment, killer shrimp and golden mussels were classified with moderate and low potential for introduction, respectively, but high for establishment and environmental impacts in the Great Lakes (Fusaro et al. 2016), which ranks them as a higher priority for control by managers and policy makers. Our results were consistent with this risk assessment for establishment and impacts, and provided quantitative evaluations and underlying mechanisms.

Our scenario simulations indicated that predators could help control the biomass of invasive ruffe and killer shrimp. Introducing predators to control invasive species has been used successfully in the past in the Great Lakes (Dettmers et al. 2012; Madenjian et al. 2002). For example, invasive alewife became hyperabundant in Lake Michigan after removal of top predators through overfishing and sea lamprey predation, and its populations were reduced by stocking piscivorous Pacific salmonids and native lake trout (Dettmers et al. 2012). In Lake Erie, predation by walleye and yellow perch may partially explain why the alewife population did not reach high levels and experience massive die-offs during severe winters as happened in Lake Michigan in the early 1950s (Dettmers et al. 2012). Similarly, Nile perch Lates niloticus became the dominant species 20 years after invading Lake Victoria, East Africa, owing to overfishing of its predators (Goudswaard et al. 2008). Thus, fishery management may enhance the control of newly introduced AIS by maintaining a desired level of predation pressure. However, stocking predators to control invasive species is less desirable an option owing to the potential for introduced predators to subsequently become invasive themselves or cause other non-target effects (Cory and Myers 2000).

Controlling golden mussels may be more problematic in Lake Erie, since golden mussels would likely be under bottom-up control and Lake Erie is highly productive. However, competitive filtration by Dreissena may prevent high population growth of golden mussel. There is evidence that Dreissena biomass declined after reaching a carrying capacity (Karateyev 
2014), and our scenario simulations of low prey vulnerability indicated golden mussel would not be able to reach a high equilibrium biomass. Therefore, as discussed above, although golden mussels may thrive in localized environments that are not suitable for Dreissena, they may be limited in other areas where Dreissena has invaded first.

\section{Conclusions}

Consistent with our hypotheses, golden mussels, which feed on the lowest trophic level, reached the highest biomass level and had the greatest direct and indirect effects on the food web, thus posing a higher ecological risk to Lake Erie. On a relative basis, ruffe and killer shrimp may have weaker effects on their predators and prey, and are less likely to affect other food web groups that indirectly interact with them. While many factors can determine the ultimate biomass that an invasive species may achieve in a new environment, the effects of food web structure and vulnerability to predators can modify their eventual equilibrium biomass. Ruffe and killer shrimp would likely be controlled by top-down predation, while golden mussel biomass would largely be affected by prey vulnerability in Lake Erie.

An ecosystem modeling approach can inform prediction of invasive species impacts with explicit consideration of within- and across-taxa variation in trophic interactions, and analyses of complex interactions between invaders and their biotic and abiotic environments (Ricciardi et al. 2013). Moreover, ecosystem models can improve the understanding of spatial and temporal variation in AIS impacts, provide mechanistic explanation of the "realized" impacts, and disentangle effects of confounding factors. Although ecosystem models have their own limitations, such as time-costly development and over parameterization, the number of developed ecosystem models has increased rapidly with needs for ecosystem-based management (Colléter et al. 2015), which makes such models a feasible tool to explore ecosystem-level effects of invasive species and consider implications for management actions to reduce impacts.

Acknowledgements We acknowledge financial support from the Environmental Protection Agency Great Lakes Restoration
Initiative, NOAA Center for Sponsored Coastal Ocean Research (CSCOR) Awards NA09NOS4780192 and NA10NOS4780218, and NSF CNIC Award 1322540. We also appreciate access to data collected by Lake Erie monitoring agencies (US EPA GLNPO, ODNR, MDNR, NYSDEC, USGS and OMNRF). We thank V. Christensen, S. Lai, and J. Steenbeek for model consultation. Initial development of the Lake Erie Ecopath model was conducted by co-authors X. Zhu and T. B. Johnson, which was supported by the Canada-Ontario Agreement Respecting the Great Lakes Basin Ecosystem. This is NOAA GLERL Contribution No. 1911.

Open Access This article is distributed under the terms of the Creative Commons Attribution 4.0 International License (http:// creativecommons.org/licenses/by/4.0/), which permits unrestricted use, distribution, and reproduction in any medium, provided you give appropriate credit to the original author(s) and the source, provide a link to the Creative Commons license, and indicate if changes were made.

\section{References}

Adams CE, Maitland PS (1998) The Ruffe population of Loch Lomond, Scotland: its introduction, population expansion, and interaction with native species. J Great Lakes Res 24:249-262

Ahrens RNM, Wlters CJ, Christensen V (2011) Foraging arena theory. Fish Fish https://doi.org/10.1111/j.1467-2979. 2011.00432.x

Baldwin NA, Saalfeld RW, Dochoda MR, et al (2009) Commercial Fish Production in the Great Lakes 1867-2006 (online). http://www.glfc.org/databases/commercial/ commerc.php. Accessed 12 Feb 2018

Balshine S, Verma A, Chant V et al (2005) Competitive interactions between round gobies and logperch. J Great Lakes Res 31:68-77

Berezina NA, Duriš Z (2008) First record of the invasive species Dikerogammarus villosus (Crustacea: Amphipoda) in the Vltava River (Czech Republic). Aquat Invasions 3:455-460

Blukacz-Richards EA, Koops MA (2012) An integrated approach to identifying ecosystem recovery targets: application to the Bay of Quinte. Aquat Ecosyst Health Manag 15:464-472

Bollache L, Dick JTA, Farnsworth KD et al (2008) Comparison of the functional responses of invasive and native amphipods. Biol Lett 4:166-169

Bolsenga SJ, Herdendorf CE (1993) Lake Erie and Lake St. Clair Handbook. Wayne State University Press, Detroit, MI

Boltovskoy D, Correa N, Cataldo D et al (2006a) Dispersion and ecological impact of the invasive freshwater bivalve Limnoperna fortunei in the Rio de la Plata watershed and beyond. Biol Invasions 8:947-963

Boltovskoy D, Correa N, Cataldo D et al (2006b) Dispersion and ecological impact of the invasive freshwater bivalve Limnoperna fortunei in the Río de la plata watershed and beyond. Biol Invasions 8:947-963 
Boltovskoy D, Karatayev A, Burlakova L et al (2009) Significant ecosystem-wide effects of the swiftly spreading invasive freshwater bivalve Limnoperna fortunei. Hydrobiologia 636:271-284

Botts PS, Patterson BA, Schloesser DW (1996) Zebra mussel effects on benthic invertebrates: physical or biotic? J N Am Benthol Soc 15:179-184

Bovy HC, Barrios-O'Neill D, Emmerson MC et al (2015) Predicting the predatory impacts of the "demon shrimp" Dikerogammarus haemobaphes, on native and previously introduced species. Biol Invasions 17:597-607

Brenton BD (1998) Simulating the effects of invasive ruffe (Gymnocephalus cernuus) on native yellow perch (Perca flavescens) and walleye (Stizostedion vitreum vitreum) population dynamics in Great Lakes waters. School of Natural Resources and Environment University of Michigan, MS thesis

Bronte CR, Evrard LM, Brown WP et al (1998) Fish community changes in the St. Louis river Estuary, Lake Superior, 1989-1996: is it ruffe or population dynamics? J Great Lakes Res 24:309-318

Burlakova LE, Barbiero RP, Karatayev AY et al (2018) The benthic community of the Laurentian Great Lakes: analysis of spatial gradients and temporal trends from 1998 to 2014. J Great Lakes Res 44:600-617

Casellato S, Visentin A, Piana GL (2007) The predatory impact of Dikerogammarus villosus on fish. In: Gherardi F (ed) Biological invaders in inland waters: profiles, distribution, and threats. Springer, Dordrecht, pp 495-506

Christensen V, Walters CJ (2004) Ecopath with Ecosim: methods, capabilities and limitations. Ecol Model 172:109-139

Church K, Iacarella JC, Ricciardi A (2017) Aggressive interactions between two invasive species: the round goby (Neogobius melanostomus) and the spinycheek crayfish (Orconectes limosus). Biol Invasions 19:425-441

Colléter M, Valls A, Guitton J et al (2015) Global overview of the applications of the Ecopath with Ecosim modeling approach using the EcoBase models repository. Ecol Model 302:42-53

Cory JS, Myers JH (2000) Direct and indirect ecological effects of biological control. Trends Ecol Evol 15:137-139

Darrigran G, Damborenea C (2011) Ecosystem engineering impact of Limnoperna fortunei in South America. Zoolog Sci 28:1-7

David P, Thébault E, Anneville O et al (2017) Chapter oneimpacts of invasive species on food webs: a review of empirical data. In: Bohan DA, Dumbrell AJ, Massol F (eds) Advances in ecological research. Academic Press, Cambridge, pp 1-60

Davidson CB, Gottschalk KW, Johnson JE (1999) Tree mortality following defoliation by the European Gypsy Moth (Lymantria dispar L.) in the United States: a review. Forest Sci 45:74-84

Dettmers JM, Goddard CI, Smith KD (2012) Management of alewife using pacific salmon in the great lakes: whether to manage for economics or the ecosystem? Fisheries 37:495-501

Devin S, Beisel JN, Bachmann V et al (2001) Dikerogammarus villosus (Amphipoda: Gammaridae): another invasive species newly established in the Moselle river and French hydrosystems. Ann Limnol-Int J Lim 37:21-27

Devine JA, Adams CE, Maitland PS (2000) Changes in reproductive strategy in the ruffe during a period of establishment in a new habitat. J Fish Biol 56:1488-1496

Dick JTA, Platvoet D, Kelly DW (2002) Predatory impact of the freshwater invader Dikerogammarus villosus (Crustacea: Amphipoda). Can J Fish Aquat Sci 59:1078-1084

Dick JTA, Alexander ME, Jeschke JM et al (2014) Advancing impact prediction and hypothesis testing in invasion ecology using a comparative functional response approach. Biol Invasions 16:735-753

Dodd JA, Dick JTA, Alexander ME et al (2014) Predicting the ecological impacts of a new freshwater invader: functional responses and prey selectivity of the 'killer shrimp', Dikerogammarus villosus, compared to the native Gammarus pulex. Freshw Biol 59:337-352

Dorcas ME, Willson JD, Reed RN et al (2012) Severe mammal declines coincide with proliferation of invasive Burmese pythons in Everglades National Park. Proc Natl Acad Sci 109:2418-2422

Drake JM, Lodge DM (2004) Global hot spots of biological invasions: evaluating options for ballast-water management. Proc R Soc B Biol Sci 271:575-580

Fullerton AH, Lamberti GA, Lodge DM et al (1998) Prey preferences of Eurasian Ruffe and yellow perch: comparison of laboratory results with composition of Great Lakes Benthos. J Great Lakes Res 24:319-328

Fusaro A, Baker A, Conard W, et al (2016) A risk assessment of potential Great Lakes aquatic invaders. NOAA Technical Memorandum GLERL-169. https://www.glerl.noaa.gov/ pubs/tech_reports/glerl-169/tm-169.pdf. Accessed 21 July 2017

Gergs R, Rothhaupt K-O (2008) Effects of zebra mussels on a native amphipod and the invasive Dikerogammarus villosus: the influence of biodeposition and structural complexity. J N Am Benthol Soc 27:541-548

Goudswaard K, Witte F, Katunzi EFB (2008) The invasion of an introduced predator, Nile perch (Lates niloticus, L.) in Lake Victoria (East Africa): chronology and causes. Environ Biol Fishes 81:127-139

Gutsch M, Hoffman J (2016) A review of Ruffe (Gymnocephalus cernua) life history in its native versus non-native range. Rev Fish Biol Fish 26:213-233

Haas G, Brunke M, Streit B (2002) Fast turnover in dominance of exotic species in the rhine river determines biodiversity and ecosystem function: an affair between amphipods and mussels. In: Leppäkoski E, Gollasch S, Olenin S (eds) Invasive aquatic species of Europe. Distribution, impacts and management. Springer, Dordrecht, pp 426-432

Harrington LA, Harrington AL, Yamaguchi N et al (2009) The impact of native competitors on an alien invasive: temporal niche shifts to avoid interspecific aggression. Ecology 90:1207-1216

Hellmann C, Schöll F, Worischka S et al (2017) River-specific effects of the invasive amphipod Dikerogammarus villosus (Crustacea: Amphipoda) on benthic communities. Biol Invasions 19:381-398

Heymans JJ, Sumaila UR, Christensen V (2009) Policy options for the northern Benguela ecosystem using a multispecies, multifleet ecosystem model. Prog Oceanogr 83:417-425 
Holker F, Temming A (1996) Gastric evacuation in ruffe (Gymnocephalus cernuus (L)) and the estimation of food consumption from stomach content data of two $24 \mathrm{~h}$ fisheries in the Elbe Estuary. Arch Fish Mar Res 44:47-67

Howeth JG, Gantz CA, Angermeier PL et al (2016) Predicting invasiveness of species in trade: climate match, trophic guild and fecundity influence establishment and impact of non-native freshwater fishes. Divers Distrib 22:148-160

Ives JT, McMeans BC, McCann KS et al (2018) Food-web structure and ecosystem function in the Laurentian Great Lakes-Toward a conceptual model. Freshw Biol 64:1-23

Jackson MC, Ruiz-Navarro A, Britton JR (2015) Population density modifies the ecological impacts of invasive species. Oikos 124:880-887

Johannsson OE, Dermott R, Graham DM et al (2000) Benthic and pelagic secondary production in Lake Erie after the invasion of Dreissena spp. with implications for fish production. J Great Lakes Res 26:31-54

Johnson TB, Bunnell DB, Knight CT (2005) A potential new energy pathway in central Lake Erie: the round goby connection. J Great Lakes Res 31:238-251

Jůza T, Blabolil P, Baran R et al (2017) Collapse of the native ruffe (Gymnocephalus cernua) population in the Biesbosch lakes (the Netherlands) owing to round goby (Neogobius melanostomus) invasion. Biol Invasions 20:1523-1535

Kangur K, Kangur A (1996) Feeding of ruffe (Gymnocephalus cernuus) in relation to the abundance of benthic organisms in Lake Vortsjarv (Estonia). Ann Zool Fenn 33:473-480

Kao Y-C, Adlerstein S, Rutherford E (2014) The relative impacts of nutrient loads and invasive species on a Great Lakes food web: An Ecopath with Ecosim analysis. J Great Lakes Res 40(Supplement 1):35-52

Karatayev AY, Boltovskoy D, Padilla DK et al (2007a) The invasive bivalves Dreissena polymorpha and Limnoperna fortunei: parallels, contrasts, potential spread and invasion impacts. J Shellfish Res 26:205-213

Karatayev AY, Padilla DK, Minchin D et al (2007b) Changes in global economies and trade: the potential spread of exotic freshwater bivalves. Biol Invasions 9:161-180

Karatayev AY, Burlakova LE, Karatayev VA et al (2010) Limnoperna fortunei versus Dreissena polymorpha: population densities and benthic community impacts of two invasive freshwater bivalves. J Shellfish Res 29:975-984

Karatayev AY, Burlakova LE, Pennuto C et al (2014) Twenty five years of changes in Dreissena spp. populations in Lake Erie. J Great Lakes Res 40:550-559

Keller RP, Drake JM (2009) Trait-based risk assessment for invasive species. In: Lodge DM, Lewis MA, Shogren JF, Keller RP (eds) Bioeconomics of invasive species. Oxford University Press, New York, pp 44-62

Keller RP, Drake JM, Drew MB et al (2011) Linking environmental conditions and ship movements to estimate invasive species transport across the global shipping network. Divers Distrib 17:93-102

Kitchell JF, Cox SP, Harvey CJ et al (2000) Sustainability of the Lake Superior fish community: interactions in a food web context. Ecosystems 3:545-560

Kováč V (1998) Biology of Eurasian Ruffe from Slovakia and adjacent Central European countries. J Great Lakes Res 24:205-216
Kramer AM, Annis G, Wittmann ME et al (2017) Suitability of Laurentian Great Lakes for invasive species based on global species distribution models and local habitat. Ecosphere 8:e01883

Krisp H, Maier G (2005) Consumption of macroinvertebrates by invasive and native gammarids: a comparison. J Limnol 64:55-59

Kulhanek SA, Ricciardi A, Leung B (2011) Is invasion history a useful tool for predicting the impacts of the world's worst aquatic invasive species? Ecol Appl 21:189-202

Langseth BJ (2012) An assessment of harvest policies for a multi-species fishery in Lake Huron using a food-web model. Department of Fisheries and Wildlife, Michigan State University, East Lansing, MI, p 48824

Laverty C, Green KD, Dick JTA et al (2017) Assessing the ecological impacts of invasive species based on their functional responses and abundances. Biol Invasions 19:1653-1665

Leung B, Lodge DM, Finnoff D et al (2002) An ounce of prevention or a pound of cure: bioeconomic risk analysis of invasive species. Proc R Soc Lond Ser B Biol Sci 269:2407-2413

Levine JM, D'Antonio CM (2003) Forecasting biological invasions with increasing international trade predicción de las invasiones biológicas con el incremento del comercio internacional. Conserv Biol 17:322-326

Lodge DM (1993) Biological invasions: lessons for ecology. Trends Ecol Evol 8:133-137

Lodge DM, Simonin PW, Burgiel SW et al (2016) Risk analysis and bioeconomics of invasive species to inform policy and management. Annu Rev Environ Resour 41:453-488

Lumb CE, Johnson TB (2012) Retrospective growth analysis of lake whitefish (Coregonus clupeaformis) in Lakes Erie and Ontario, 1954-2003. Adv Limnol 63:429-454

Maazouzi C, Piscart C, Legier F et al (2011) Ecophysiological responses to temperature of the "killer shrimp" Dikerogammarus villosus: is the invader really stronger than the native Gammarus pulex? Comp Biochem Physiol A Mol Integr Physiol 159:268-274

Maccoux MJ, Dove A, Backus SM et al (2016) Total and soluble reactive phosphorus loadings to Lake Erie: a detailed accounting by year, basin, country, and tributary. J Great Lakes Res 42:1151-1165

MacNeil C, Dick JTA, Platvoet D et al (2011) Direct and indirect effects of species displacements: an invading freshwater amphipod can disrupt leaf-litter processing and shredder efficiency. J N Am Benthol Soc 30:38-48

Macneil C, Boets P, Lock K et al (2013) Potential effects of the invasive 'killer shrimp' (Dikerogammarus villosus) on macroinvertebrate assemblages and biomonitoring indices. Freshw Biol 58:171-182

Madenjian CP, Fahnenstiel GL, Johengen TH et al (2002) Dynamics of the Lake Michigan food web, 1970-2000. Can J Fish Aquat Sci 59:736-753

Madgwick G, Aldridge D (2011) Killer shrimps in Britain: hype or horror? Br Wildl 22:408-412

Mandrak NE (1989) Potential invasion of the great lakes by fish species associated with climatic warming. J Great Lakes Res 15:306-316

Marbuah G, Gren I-M, McKie B (2014) Economics of harmful invasive species: a review. Diversity 6:500 
Mayer G, Maier G, Maas A et al (2009) Mouthpart morphology of Gammarus roeselii compared to a successful invader, Dikerogammarus villosus (Amphipoda). J Crustac Biol 29:161-174

ODW (2017) Ohio's Lake Erie Fisheries, 2016. Annual status report. Federal Aid in Fish Restoration Project F-69-P. Ohio Department of Natural Resources, Division of Wildlife, Lake Erie Fisheries Units, Fairport and Sandusky. p 123. https://wildlife.ohiodnr.gov/portals/wildlife/pdfs/ fishing/LakeErieStatus.pdf. Accessed 12 Feb 2018

Ogle DH (1998) A synopsis of the biology and life history of ruffe. J Great Lakes Res 24:170-185

Ogle DH, Selgeby JH, Newman RM et al (1995) Diet and feeding periodicity of Ruffe in the St-Louis River Estuary, Lake-Superior. Trans Am Fish Soc 124:356-369

Parker IM, Simberloff D, Lonsdale WM et al (1999) Impact: toward a framework for understanding the ecological effects of invaders. Biol Invasions 1:3-19

Patterson MWR, Ciborowski JJH, Barton DR (2005) The distribution and abundance of Dreissena species (Dreissenidae) in Lake Erie, 2002. J Great Lakes Res 31:223-237

Pestana D, Ostrensky A, Boeger WAP et al (2009) The effect of temperature and body size on filtration rates of Limnoperna fortunei (Bivalvia, Mytilidae) under laboratory conditions. Braz Arch Biol Technol 52:135-144

Peterson GS, Hoffman JC, Trebitz AS et al (2011) Establishment patterns of non-native fishes: lessons from the Duluth-Superior harbor and lower St. Louis River, an invasion-prone Great Lakes coastal ecosystem. J Great Lakes Res 37:349-358

Pimentel D (2005) Aquatic nuisance species in the New York State Canal and Hudson River systems and the Great Lakes Basin: an economic and environmental assessment. Environ Manag 35:692-701

Pimentel D, Zuniga R, Morrison D (2005) Update on the environmental and economic costs associated with alien-invasive species in the United States. Ecol Econ 52:273-288

Platvoet D, van der Velde G, Dick J et al (2009) Flexible omnivory in Dikerogammarus villosus (Sowinsky, 1894) (Amphipoda)-Amphipod Pilot Species Project (AMPIS) report 5. Crustaceana 82:703-720

Pothoven SA, Madenjian CP (2008) Changes in consumption by alewives and lake whitefish after dreissenid mussel invasions in Lakes Michigan and Huron. N Am J Fish Manag 28:308-320

Pothoven SA, Madenjian CP, Höök TO (2017) Feeding ecology of the walleye (Percidae, Sander vitreus), a resurgent piscivore in Lake Huron (Laurentian Great Lakes) after shifts in the prey community. Ecol Freshw Fish 26:676-685

Pratt DM, Blust WH, Selgeby JH (1992) Ruffe, Gymnocephalus-Cernuus-Newly Introduced in North-America. Can J Fish Aquat Sci 49:1616-1618

Rewicz T, Grabowski M, MacNeil C et al (2014) The profile of a "perfect" invader-the case of killer shrimp, Dikerogammarus villosus. Aquat Invasions 9:267-288

Rezsu E, Specziár A (2006) Ontogenetic diet profiles and sizedependent diet partitioning of ruffe Gymnocephalus cernuus, perch Perca fluviatilis and pumpkinseed Lepomis gibbosus in Lake Balaton. Ecol Freshw Fish 15:339-349
Ricciardi A (1998) Global range expansion of the Asian mussel Limnoperna fortunei (Mytilidae): another fouling threat to freshwater systems. Biofouling 13:97-106

Ricciardi A, Hoopes MF, Marchetti MP et al (2013) Progress toward understanding the ecological impacts of nonnative species. Ecol Monogr 83:263-282

Seebens H, Gastner MT, Blasius B (2013) The risk of marine bioinvasion caused by global shipping. Ecol Lett 16:782-790

Šidagyte E, Solovjova S, Šniaukštaite V et al (2017) The killer shrimp Dikerogammarus villosus (Crustacea, Amphipoda) invades Lithuanian waters, South-Eastern Baltic Sea. Oceanologia 59:85-91

Simberloff D (2013) Biological invasions: prospects for slowing a major global change. Elem Sci Anth 1:000008

Simberloff D, Von Holle B (1999) Positive interactions of nonindigenous species: invasional meltdown? Biol Invasions 1:21-32

Sylvester F, Dorado J, Boltovskoy D et al (2005) Filtration rates of the invasive pest bivalve Limnoperna fortunei as a function of size and temperature. Hydrobiologia 534:71-80

Sylvester F, Boltovskoy D, Cataldo DH (2007) Fast response of freshwater consumers to a new trophic resource: predation on the recently introduced Asian bivalve Limnoperna fortunei in the lower Parana river, South America. Austral Ecol 32:403-415

Taylor NG, Dunn AM (2017) Size matters: predation of fish eggs and larvae by native and invasive amphipods. Biol Invasions 19:89-107

USGS (2015) Great Lakes Commercial Fishing Catches 1929-2013. USGS Great Lakes Science Center Commercial Fishing Reports https://www.glsc.usgs.gov/ commercial-fishing-reports

Vanderploeg HA, Nalepa TF, Jude DJ et al (2002) Dispersal and emerging ecological impacts of Ponto-Caspian species in the Laurentian Great Lakes. Can J Fish Aquat Sci 59:1209-1228

Vanderploeg HA, Bunnell DB, Carrick HJ et al (2015) Complex interactions in Lake Michigan's rapidly changing ecosystem. J Great Lakes Res 41:1-6

Vilà M, Pujadas J (2001) Land-use and socio-economic correlates of plant invasions in European and North African countries. Biol Cons 100:397-401

Volta P, Jeppesen E, Campi B et al (2013) The population biology and life history traits of Eurasian ruffe [Gymnocephalus cernuus (L.), Pisces: Percidae] introduced into eutrophic and oligotrophic lakes in Northern Italy. J Limnol 72:280-290

Winfield IJ, Adams CE, Fletcher JM (1996a) Recent introductions of the ruffe (Gymnocephalus cernuus) to three United Kingdom lakes containing Coregonus species. Ann Zool Fenn 33:459-466

Winfield IJ, Adams CE, Fletcher JM (1996b) Recent introductions of the ruffe (Gymnocephalus cernuus) to three United Kingdom lakes containing Coregonus species. Ann Zool Fenn 33:459-466

Yokomizo H, Possingham HP, Thomas MB et al (2009) Managing the impact of invasive species: the value of knowing the density-impact curve. Ecol Appl 19:376-386 
Zhang H, Rutherford ES, Mason DM et al (2016) Forecasting the impacts of silver and bighead carp on the Lake Erie Food Web. Trans Am Fish Soc 145:136-162

Zhou YT, Obenour DR, Scavia D et al (2013) Spatial and temporal trends in Lake Erie Hypoxia, 1987-2007. Environ Sci Technol 47:899-905
Publisher's Note Springer Nature remains neutral with regard to jurisdictional claims in published maps and institutional affiliations. 